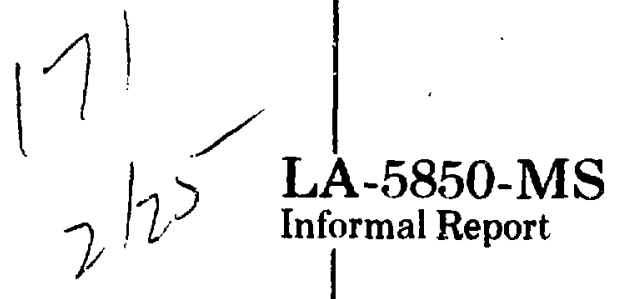

UC-4

Reporting Dace: January 1975 Issued: February 1975

\title{
Chemical Equilibria in Hot Air with Moisture, Salt, and Vaporized Metal Contaminants
}

by

John Zinn

C. Dexter Sutherland

selomilite laboratory

of the Universify of California

LOS ALAMOS, NEW MEXICO 87544

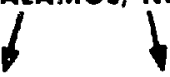

An Affirmative Action/Equol Opportunity Employer

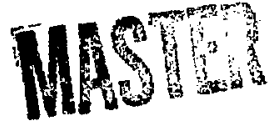


In the interest of prompt distribution, this LAMS report was not edited by the Technical Information staff.

Work partially supported by the Defense Nuclear Agency.

Printed in the Unilod State of America. Available trom National Technical Information Sorvice

U.S. Departmenl of Commerce

5285 Port Royal Road

Springtield, VA 22151
Price: Printed Copy $\$ 4.00$ Microtiche $\$ 2.25$

The soport wan propared au an accoulat af work nponeored by the Unutod

Stow Govarnmeat Northel the Uniled Stote sor the Uniled Srave

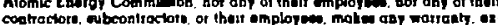

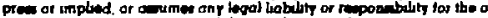

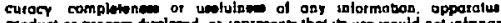

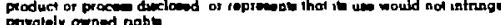


CHEMICAL EQUILIBRIA IN HOT AIR

WITH MOISTURE, SALT, AND VAPORIZED METAL CONTAMINANTS

by

John $\mathrm{Zinn}$ and $\mathrm{C}$. Dexter Sutherland

ABSTRACT

This report describes computations of thermodynamic equilibrium chemical species concentrations in hot (300-6000 K) air with and without moisture, salt, and metallic contaminants. The importance of the salt and metal vapors stems from the fact that small concentrations can lead to greatly enhanced levels of ionization. Estimated thermodynamic functions are tabulated for 46 different complex molecular and polyatomic ions, and these ions are included in the equilibrium computations. The thermodynamic parameters are used for generating reaction rat; coefficients for otherwise uninvestigated reactions which are the reverses of known reactions.

\section{INTRODUCTION}

This report describes computations of equilibrium chemical composition of hot air in the temperature range 300 to $6000 \mathrm{~K}$. They are not the first computations of their kind, similar ones having been reported earlier by Gilmore, ${ }^{1,2}$ Hilsenrath, 3,4 and others. However, they are probably unique in the number of molecular species that they include. We also include estimates of specific heats, entropies, and free energies of formation for a number of complex ions. Our motivation for this work grew out of a need to compute electron and ion densities in hot air in various nuclear radiation environments. This is the first of a pair of reports on that general subject. The second, which is in preparation, describes the nonequilibrium chemical kinetics. 5

In hot air the list of important rate processes includes many reactions which are unimportant at lower temperatures, and whose rates are not easily measurable. A satis- factory computation of the time dependence of the chemical composition would have to include all of the important reactions. An obvious practical test of the completeness of a set of reactions for chemical kinetics computations at a given temperature is that the thermodynamic equilibrium set of species concentrations should turn out to be a stable solution to the rate equations. That is, if the equilibrium concentrations are introduced as initial conditions, and if there are no nonequilibrium sources or sinks (no nonequilibrium radiation fluxes, for example), the rates of change of the concentrations should come out to be zero. To perform this computational experiment, it is of course necessary to compute the equilibrium composition--hence these computations.

To be able to pass the above test, the chemical reaction set must be complete in the sense that each reaction is matched by a corresponding reverse reaction, and the

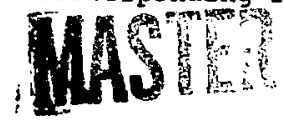


ratio of each pair of forward and reverse rate coefficients is the equilibriun constant. In most cases, published rate coefficient data are for enothermic reactions. and rate coefficients for the reverse, ondothermic, reaction paths are not given. To complete the set, therefore, we must furnish the set of reverse rate coefficients, and to do this we must calculate equilibrium constants. The latter task is simpler than the computation of equilibrium species concentrations. However, it reguires the same set of input thermodynamic parameters, and is therefore within the context of this report.

Section II of this report describes the mathematics and numerical scheme for the computations of chemical equilibria. Section III gives the input thermodynamic parameters and the prescriptions used for estimating some that were rot otherwise known, Section IV describes computed equilibrium compositions for hot air at various temperatures for various values of pressure and relative humidity. We also discuss the effects on electron and ion densities produced by atmospheric Nac\% aerosol and vaporized metal contaminants. Section $v$ contains a description of the calculation of equilibrium constants and reverse reaction rate coefficients.

\section{COMPUTATIONS OF CHEMICAL EQUILIBRIA}

A. Mixtures of Ideal Gases at constant Temperature and Pressure

For any system at constant temperature $T$ and pressure $P$ the state of thermodynamic equilibrium is the state of minimum Gibbs free energy $\mathrm{F}$. We shall consider a mixture of ideal gases in which the numbers of moles $N_{i}$ of individual constituent molecular species (subscript i) are variable, subject to the constraints of constant $T$ and $P$ and constant numbers of gram atoms $n_{j}$ of constituent chemical elements (subscript j). The free energy ic an ideal gas mixture of variable composition is given by

$$
\begin{aligned}
F & =\left\{N_{i} \widetilde{F}_{i}\right. \\
& =\sum_{i} N_{i}\left(\vec{F}_{i}^{0}+R T \ln \left(P N_{i} / \sum_{k} N_{k}\right)\right\}
\end{aligned}
$$

where $\bar{F}_{i}$ is the molar fret enetgy of opecies i. $\vec{F}_{i}^{0}$ is the atandard molar free energy, and $P$ is the pressure in atmospheres. " The congtraint that the total amounts of the constituent elementh are constant to expressed $\mathbf{a s}$

$$
\sum_{i} a_{i j} N_{i}-n_{j}=0
$$

where the $a_{i j}$ are atolchtometric coefficients (number of atoms of element $j$ in conpound i). The equilibrium state is the state of minimum $F$ consistent with the constraints. We shall find the equilibrium set of $N_{i}$ by the method of Lagrange multiplier:

We define a set of conetraint functions

$$
Q_{j} \equiv \sum_{i} a_{i j} N_{i}-n_{j}
$$

and Lagrange multipliers $\lambda_{j}$. since the constraints require that $Q_{j}=0$ (for $a 11 \mathrm{jl}$. a minimum of $F$ consistent with the constraints implies a minimum of the function

$$
G \equiv F+\sum_{j} \lambda_{j} Q_{j}
$$

A necessary condition for a minimum of $G$ is that the partial derivatives of $G$ with respec to the $N_{i}$ and the $\lambda_{j}$ are all zero. This leads to the equations

$$
\begin{aligned}
\frac{\partial G}{\partial N_{i}} & =\bar{F}_{i}^{0}+R T \ln \left(P N_{i} / \sum_{k} N_{k}\right)+\sum_{j} \lambda_{j} a_{i j} \\
& =0
\end{aligned}
$$

*Footnote: We have selected the convention that the heats of formation of elements in their reference states are zero at all temperatures, The same convention is uaed in the JANAF ${ }^{6}$ thermochemical tables. 
and

$$
\frac{\partial G}{\partial \pi_{j}}+\sum_{i} a_{i j} v_{i}-n_{j}=0 .
$$

where $r$, $p$, the $F_{i}^{0}, n_{j}$, and $a_{i j}$ are all qiven quantitiea, $i=1,2, \ldots i_{\max }$ and $j=1,2 \ldots j_{\max }$. The sbove congtitute $i_{\max }+j_{\max }$ equations for the $i_{\max }+j_{\max }$ unknowns ${ }^{*}$ and $\lambda_{j}$.

The conditinn of charge conservation 1. incorporated natarally in these equaciona. The net chaxge is treated as a chomical element of zero concentration, with stoichlomstric coefficients which are negative for olccerone or negative ions, zero for newerals, and frositive for posielve lons.

Ecjuations (5) and (6) are, of courso. nonlinear. To fing solutions. we caploy a Hewton-Raphen iterative procedure. Let us denote the unknown quantities by $x_{j}$. the set of equationa by $y_{i}\left(x_{j}\right)=0$, and the zeros of the equations by $\bar{x}_{j}(i, j)=1 \ldots$ $i_{\max }+J_{\max } \mid$. A set of inteial yucsses $x_{j}(0)$ is made for a sequence $x_{j}$ (N) . converging to $\bar{x}_{j}$. The cquations aro mproximated by firstorder Taylor series expansons about $\bar{x}_{j}$. Define $x_{j}(N)-\bar{x}_{j}=x_{j}$ and note that $y_{i}\left(\bar{X}_{j}\right)=0$. Thon the Tayiar expansions aro

$$
x_{i}\left(x_{j}^{(N)}\right)=\left.\sum_{j=1}^{i_{\max }^{+y_{\max }}} \frac{\partial y_{i}}{\partial x_{j}}\right|_{x_{j}(N)} d x_{j}
$$

These equations are solved for the $d x_{j}$ by standard linesr elgebra methods. The $i x_{j}$ are then used to obtain sequential values of $x_{j}(N+1)\left[\right.$ replacing $\bar{x}_{j}$ by $\left.x_{j}(N+1)\right]$.

$$
x_{j}^{(N+1)}=x_{j}^{(N)}-\Delta x_{j} \text {. }
$$

subject to the added condition that none of the $x_{j}$ (N) ary be less than zero. The sequence of corrections is terminated when $\left|\Delta x_{j} / x_{j}(n+1)\right|$ is sufficiently small. The procedure is coded for the CDC 7600.

The general subject of chemical equilibriun computations is described in many places including the book by van zeggeren and Storey. 7 The Lagrange multiplier method is treated along with other methods.

Basic input data for the computer code include standard free energies $\bar{F}_{i}^{0}$ for the $i_{\text {max }}$ chemical species, as well is the stoichiometric coefficients $a_{i j}$. The $\bar{F}_{i}^{0}$ are derived mostly from the JANAF tabulations ${ }^{6}$ of molar enthalpy, free energy, etc. Some additional tabulations are available, inrluding those of Gilmore. ${ }^{8}$ Hilsenrath et a1. 9 Gurvich, 10 and clifton. 11 In cases where data do not exist, we have made our own estimates. These matters are elaborated in Scetion III.

5. Constant Density Nonideal Gas Systems

a version of the equilibrium code has been constructed for nonideal gas systems. with provision for including first and stcond virial cocfficients and Debye-hückel corraction factors. This version is applicable to systems at constant volume rather than constant pressure, and car. be used for ydeal gases at constant volume, if desired. The lielmholtz free encrgy is minimized instead of the Gibus free energy. Further discussion is beyond the scope of this report. The computed results described in section IV are all for ideal gas systems.

1II. TIERMODYNAHIC DATA

A. JMNAF Tables and Pits Thermodynamic data in the JANAF tables ${ }^{6}$ include, for individual chemical species, tabulations of standard molar heat capacity $\bar{C}_{p}^{0}$. molar enthalpy of formation $\bar{H}_{0}^{0}$, enthalpy (in the form $\bar{H}^{0}-\bar{H}_{298}^{0}$ ), entropy $\bar{S}^{0}$, free energy function $-\left(\overline{\mathrm{F}}^{0}-\overline{\mathrm{H}}_{298}^{0}\right) / \mathrm{T}$, etc. , all as functions of temperature, for temperatures up to $6000 \mathrm{~K}$. Input data for the equilibrium code are in the form of polynomial fits to these functions. The enthalpy is fitted as 


$$
\begin{aligned}
& \vec{H}^{0}-\widehat{H}_{298}^{0} \\
& \equiv\left(\vec{H}_{0}^{0}--_{298}^{0}\right)+R T\left(A+B T+C T^{2}+D T^{3}+E T^{4}\right)
\end{aligned}
$$

(i.e. simply a 5th-degree polynomial in $T$ ). It then follows that

$$
\begin{aligned}
& \left(\vec{F}^{0}-\vec{H}_{298}^{0}\right) / T \\
& =R\left(A(1-\ell \Omega T)-B T-C T^{2} / 2-D^{3} / 3-E T^{4} / 4-J\right\} \\
& +\left(\bar{H}_{0}^{0}-\vec{H}_{298}^{0}\right) / T
\end{aligned}
$$

introducing a sixth parameter, J. The coefficients $A$ through $E$ and $J$ can be derived Erom the tabulated $\bar{H}^{0}-\bar{H}_{298}^{0}$ and $\left(\bar{F}^{0}-\bar{H}_{298}^{0}\right) / T$. The fitting procedure is adapted from a report by Bird, Duff, and schott. 12 These fits are valid only within the range of the tabulated data--usually $298 \mathrm{~K} \leq \mathrm{T} \leq 6000 \mathrm{~K}$. Having $\overline{\mathrm{H}}_{0}^{0}$ and coefficients $A . . E$ and $J$ from the tables, one can generatc values of standard free energy at any temperature via

$\overrightarrow{\mathrm{F}}^{0}=\overrightarrow{\mathrm{H}}_{0}^{0}+\mathrm{RT}\left(\mathrm{A}(1-\ell \mathrm{nT})-\mathrm{BT}-\mathrm{CT} \mathrm{T}^{2} / 2-\mathrm{DT}^{3} / 3-\mathrm{ET} \mathrm{T}^{4} / 4-\mathrm{J}\right\}$

\section{B. Estimation of Thermodynamic Parameters for strange species}

Thr next section (III-C) will incluce a listing of the fitted thermodynanic coefficients $A, B, C, D, E$, and $J$ as well as $\bar{H}_{0}^{0}$ for each species included in the code, and comments on sources of information.

For purposes of generating matched forward and reverse rate coefficients for the kinetics code, it is necessary to include several compounds and complex ions that have negligible concentrations at equi1 ibrium. Examples are hydrated ions and complexes such as $\mathrm{CO}_{4}^{-}, \mathrm{O}_{4}^{+}$, and $\mathrm{O}_{4}^{-}$. To compute equilibrium constants for these species we need to provide values of free energies of formation. The latter are frequentiy not available in the literature, and must be estimated.
To provide entries in the table where published thermodynamic data are not available, we proceed by estimating first the standard heat of formation $\overrightarrow{\mathrm{H}}_{0}^{0}$, the specific heat $\bar{c}_{p}^{0}$, and the $298 \mathrm{k}$ entropy $\bar{s}_{298^{\circ}}^{0}$ In some cases published values of $\overline{\mathrm{H}}_{0}^{0}$ are available while $\bar{c}_{p}^{0}$ and $\bar{s}^{0}$ are not. We have had to estimate heats of formation only for some hydrated ions and for water dimer and trimer. In the absence of other information we have assumed that the heats of hydration of negative ions are all $-18.4 \mathrm{kcal} /$ mole for the first attached water molecule and $-10.7 \mathrm{kcal} / \mathrm{mole}$ for the second. The value of $-18.4 \mathrm{kcal} / \mathrm{mole}$ is the alleged heat of hydration of $0_{2}^{-}, 13$ (which corresponds, incidentally, to the icn-dipole attraction energy that would exisi between a unit point charge and the 1.85 Debye water dipole at a separation distance of $2.2 \AA$ ). The $-10.7 \mathrm{kcal} / \mathrm{mole}$ is the average waterwater association energy obtained from the heat of vaporization of water. We have chosen the same value for the heat of dimerization of water and for the hydration of the dimer to trimer. For positive ion monohydrates other than those of $\mathrm{H}^{+}$and $\mathrm{H}_{3} \mathrm{O}^{+}$we have arbitrarily chosen $-20 \mathrm{kcal} / \mathrm{mole}$ as the heat of hydration. For the case of $\mathrm{H}^{+}$, $\mathrm{H}_{3} \mathrm{O}^{+}, \mathrm{W} \cdot \mathrm{H}_{3} \mathrm{O}^{+}$and $\mathrm{W}_{2} \mathrm{H}_{3} \mathrm{O}^{+}$(where $\mathrm{W}^{*}$ means hydrate), published heats of hydration are available (Kebarle et al.). ${ }^{14}$ The heat of hydration of $\mathrm{H}_{3} \mathrm{O}^{+}$to $\mathrm{W} \cdot \mathrm{H}_{3} \mathrm{O}^{+}$is given as $-36 \mathrm{kcal} / \mathrm{mole}$, for hydration of $\mathrm{w} \cdot \mathrm{H}_{3} \mathrm{O}^{+}$to $\mathrm{w}_{2} \mathrm{H}_{3} \mathrm{O}^{+}$it is $-22.3 \mathrm{kcal} / \mathrm{mole}$, and for higher hydrates it decreases monotonically, becoming $-10.3 \mathrm{kcal} / \mathrm{mole}$ for the eighth hydrate. (The $-10.3 \mathrm{kcal} / \mathrm{mole}$ is close to our assumed value of $-10.7 \mathrm{kcal} / \mathrm{mole}$ for the heat of assocjation of water.) For formation of dihydrates of positive ions other than $\mathrm{H}^{+}$or $\mathrm{H}_{3} \mathrm{O}^{+}$we assume $\Delta \mathrm{H}=-22.3 \mathrm{kcal} / \mathrm{mole}-\mathrm{i} . \mathrm{e}$. the same as the published $\Delta H$ for hydration of $\mathrm{W} \cdot \mathrm{H}_{3} \mathrm{O}^{+}$to $\mathrm{W}_{2} \mathrm{H}_{3} \mathrm{O}^{+}$.

We turn next to the problem of estimating $\bar{C}_{p}^{0}, \bar{S}_{298}^{0}$, and the related coeficients $A, B, C, D, E$, and J. According to Eq. (9) the 
heat capacity is

$\vec{C}_{p}^{0}=R\left(A+2 B T+3 C T^{2}+4 D T^{3}+5 E T^{4}\right)$

At normal temperatures (ca $298 \mathrm{~K}$ ) the contributions to $\bar{c}_{p}^{0}$ arising from translational and rotational degrees of freedom are effectively saturated in all but the lightest molecules. Certain internal rotation, torsion, and molecular bending modes also contribute to the $298 \mathrm{~K}$ heat capacity. Using the equipartition principle, we assume therefore that

$\bar{c}_{p}^{0}(298 k) \approx c_{\text {trans }}+c_{\text {rot }}+c_{\text {torsion }}+c_{\text {bend }}$ $\approx R\left(4+n_{\text {torsion }}+n_{\text {bend }}\right)$ for non-

linear molecules,

and

$\vec{c}_{p}^{0}(298 k) \approx R\left(7 / 2+n_{\text {bend }}\right)$ for linear mole-

cules.

Here $n_{\text {torsion }}$ represents the effective number of torsion and internal rotation modes populated at $298 \mathrm{k}$ and $\mathrm{n}_{\text {bend }}$ represents the number of populated bending modes. Comparisons with publishe $\$$ values of $\bar{C}_{p}^{0}(298 \mathrm{~K})$ for a number of compounds lead us to conclude that these approximations have an accuracy c. f about $\mp 1 \mathrm{cal} \mathrm{deg}^{-1}$ mole $\mathrm{e}^{-1}$.

At higher temperatures the limiting heat capacity, excluding contributions of excited electronic states, is

$$
\bar{C}_{p}^{0}(1 i m)=R\left(3 n_{\text {atoms }}-2\right) .
$$

Next we make the very drastic assumption that $\bar{C}_{p}^{0}(2298 \mathrm{k})=\overline{\mathrm{C}}_{\mathrm{p}}^{0}(1 \mathrm{im})$ and that $\overline{\mathrm{C}}_{\mathrm{p}}^{0}$ varies linearly with $T$ between 298 and $2298 \mathrm{~K}$. The choice of $2298 \mathrm{~K}$ as the temperature where $\bar{c}_{p}^{0}=\bar{c}_{p}^{0}$ (lim) is arbitrary. For most compounds $\bar{c}_{p}^{0}$ is in fact close to $\bar{c}_{p}^{0}(l i m)$ at this temperature. With this assumption we obtain, for nonlinear moleculer.

$$
\begin{aligned}
\vec{C}_{P}^{0}(T) & \approx R\left[\left(4.9+1.15 n_{t+b}-0.45 n_{a t o m s}\right)\right. \\
& \left.+T\left(-0.003-0.0005 n_{t+b}+0.0015 n_{\text {atoms }}\right)\right] .
\end{aligned}
$$

and

$$
\begin{aligned}
\bar{c}_{p}^{0}(T) & \approx R\left[\left(4.4+1.15 n_{t+b}-0.45 n_{a t o m s}\right)\right. \\
& \left.+T\left(-0.003-0.0005 n_{t+b}+0.0015 n_{a t o m s}\right)\right]
\end{aligned}
$$

for linear molecules, where we use $n_{t+b}$ as shoxthand for ( $n_{\text {torsion }}+n_{\text {bend }}$ ). These expressions are intended to apply to the temperature range $298<T<2298 \mathrm{~K}$. Above $2298 \mathrm{~K}, \overrightarrow{\mathrm{c}}_{\mathrm{p}}^{0} \approx \overrightarrow{\mathrm{c}}_{\mathrm{p}}^{0}(\mathrm{lim})$. Accordingly, the coefficients of the $f$ it become

$A=\left\{\begin{array}{rr}4.9+1.15 n_{t+b}-0.45 n_{\text {atoms }} \\ \text { (nonlinear molecules) } \\ 4.4+1.15 n_{t+b}-0.45 n_{\text {atoms }} \\ \text { (1inear molecules) }\end{array}\right.$

$B=-2.5 \times 10^{-4}\left(6+n_{t+b}-3 n_{\text {atoms }}\right)$.

and $C=D=E=0$.

These approximations are certainly very crude, but they have a relatively minor influence on the $\bar{F}^{0}$.

Now, since we set $C=D=E=0$, it

follows from Eqs. (9) and (10) that

$$
J=\frac{\bar{S}^{0}}{\bar{R}}-A \text { \&n } T-2 B T \text {. }
$$

Therefore $J$ can be determined if we know the standard entropy $\overrightarrow{\mathbf{S}}^{0}$ at some temperature. We have chosen to evaluate $J$ for $T=298 \mathrm{~K}$. For cases where published values of $\vec{s}^{0}$ are not available, we must estimate a value. The entropy of a polyatomic gas at normal temperature includes contributions fiom 
translation, ground electronic state degeneracy, rotation, and certain internal rotation, torsion, and bending modes. By the Sackur-Tetrode equation, the combined translational and ground state degeneracy contributions are

$\bar{S}_{\text {trans }}^{0}=R\left(1.5 \ell n M+2.5 \ell n T+\ell n g_{0}-1.164\right)$

where $M$ is the molecular weight in a.m.u. and $g_{0}$ is the ground state statistical weight factor. (see, for example, s. Glasstone.) 15 The rotational entropy is, for linear molecules, 15

$\overrightarrow{\mathrm{s}}_{\text {rot }}^{0}=R(\operatorname{lnI}+\ln \mathrm{T}-\ell \mathrm{n \sigma}+89.40)$,

(16a)

where $\mathrm{I}$ is the moment of inertia in $\mathrm{g} \mathrm{\textrm {cm } ^ { 2 }}$ and $\mathrm{a}$ is the symmetry number. For nonlinear molecules the rotational entropy is

$\vec{s}_{\text {rot }}^{0}=R[0.5 \ln (a b c)+1.5 \ell n T-\ell n \sigma+134.68],(16 b)$

where $a, b$, and $c$ are the three principal moments of inertia.

The vibrational entropy of small molecuies at $298 \mathrm{~K}$ and below is usually small. For $3 n-6$ simple harmonic vibrations with fundamental frequencies $\omega_{i}\left(\mathrm{~cm}^{-1}\right)$ the vibrational entropy is 15

$$
\begin{aligned}
\bar{s}_{v i b}^{0}= & R \sum_{1}^{3 n-6}\left\{u_{i} /\left[\exp \left(+u_{i}\right)-1\right]\right. \\
& \left.-\ln \left[1-\exp \left(-v_{i}\right)\right]\right\}
\end{aligned}
$$

where $u_{i} \equiv h w_{i} c / k T$.

The total entropy is

$$
\bar{s}^{0}=\bar{s}_{\text {trans }}^{0}+\bar{s}_{\text {rot }}^{0}+\bar{s}_{v i b}^{0}
$$

In many cases we have neither the molecular structure information needed for computing $I$ or abc nor the vibrztional frequencies $w_{i}$. For a number of cases we have guessed at moments of inertia (see Appen$\mathrm{dix})$, and the errors in $\bar{S}_{\text {rot }}^{0}(298 \mathrm{~K})$ from errors in these estimates are probably within $\mp 2 \mathrm{cal} / \mathrm{mole} k$. We have also guessed at vibrational frequencies. For molecules with internal rotation, torsion, or bending modes, the potential errors in $\overline{\mathbf{s}}_{\mathrm{vib}}^{0}(298 \mathrm{~K})$ from errors in these guesses may be as large as $\mp 3 n_{t+b}$ cal/mole $k$. Details of the assuned structures, vibrational frequencies, etc. are given in the Appendix, along with calculated thermodynamic parameters.

c. Tabulation of the Thermodynamic Parameters

Table I is a listing, for each chemical species, of the coefficients A, B, C, D, E, and $J$ derived from fits to published thermodynamic data or calculated by the recipes in the previous section. Also tabulated are the heats of formation $\overrightarrow{\mathrm{H}}_{0}^{0}$, entropies $\overrightarrow{\mathrm{s}}_{298 \mathrm{~K}}^{0}$, and references to literature or other sources.

\section{EQUILIBRIUM COMPOSITION OF HOT AIR} We have performed seven sets of computations of the composition of air over a range of temperatures, and the results are displayed in graph form in Figs. 1 through 7. The computations include all of the chemical species listed in Table $I$.

Figures $1(a, b)$ represent a series of cases for pure dry air at 1 atmosphere pressure. The plot gives the mole fractions of constituent chemical species (in the range $10^{-7}$ to 1) as funstions of temperature. In this set of calculations the atom fractions of $\mathrm{N}, 0$, Ar, and $\mathrm{C}$ are $0.784,0.211$, $4.7 \times 10^{-3}$, and $1.6 \times 10^{-4}$ respectively, and no other elements are included. The computations are extended to $8000 \mathrm{~K}--\mathrm{slightly}$ beyond the range of the thermodynamic data.

The total particle density, by the ideal gas law, is $7.34 \times 10^{21} / \mathrm{T} \mathrm{cm}^{-3}$.

Figures $2(a, b)$ represent a similar series of runs for moist air ( 1 mole \& water) at 1 atmosphere pressure. Atom fractions of $\mathrm{N}, \mathrm{O}, \mathrm{Ar}, \mathrm{C}$, and $\mathrm{H}$ are respectively 0.773 , $0.21 .3,4.6 \times 10^{-3}, 1.6 \times 10^{-4}$, and 0.01 .

Figures $3(a, b), 4(a, b)$ and $5(a, b)$ represent three sets of computations for moist air containing $1 \mathrm{ppm}$ of NaCl. One ppm is approximately the NaCl concentration found 
ம

on

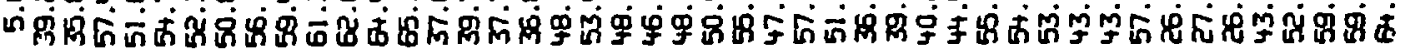

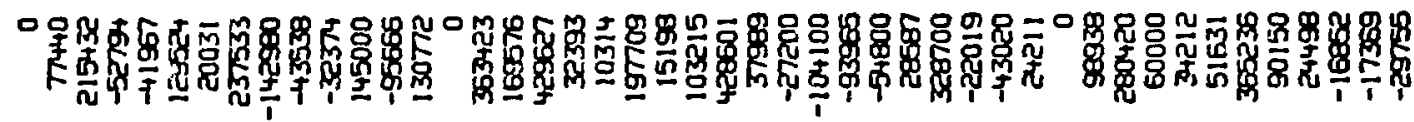

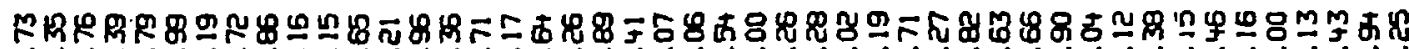

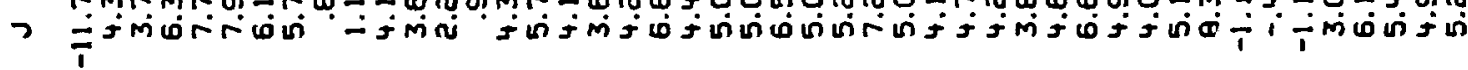

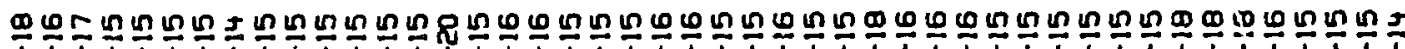

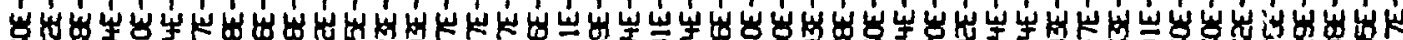

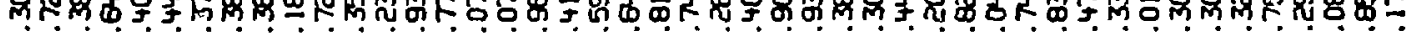

눈

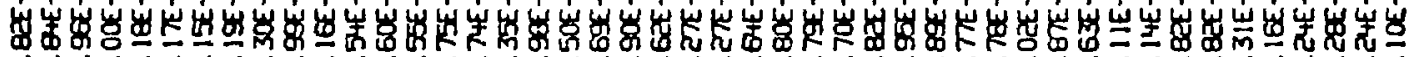

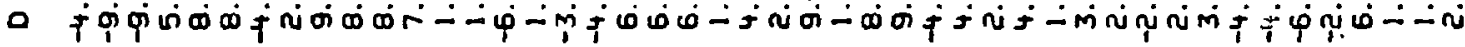

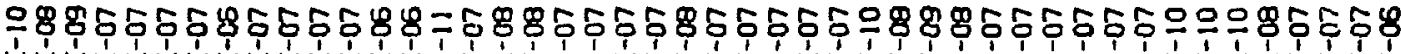

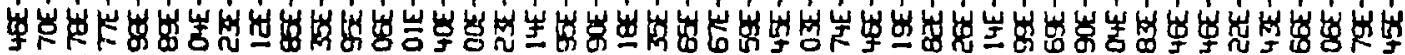

u nimpip

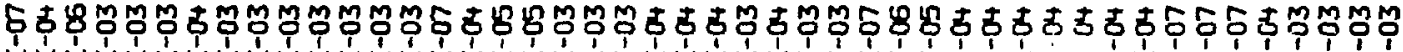

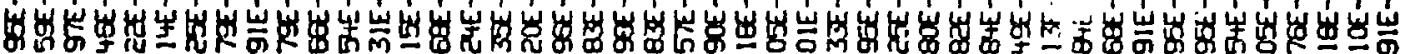

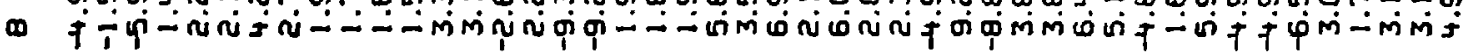

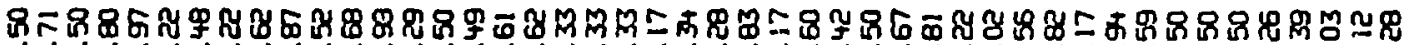

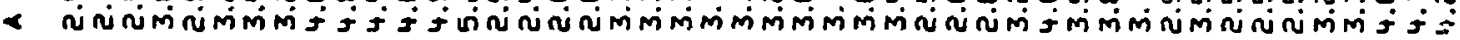

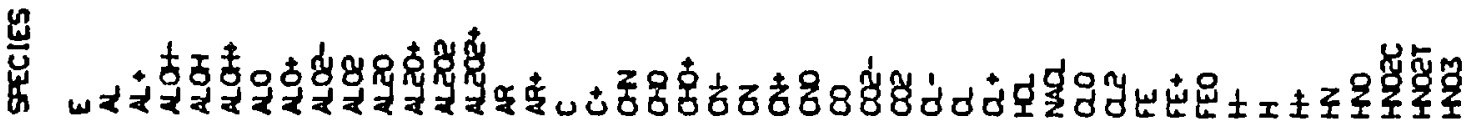




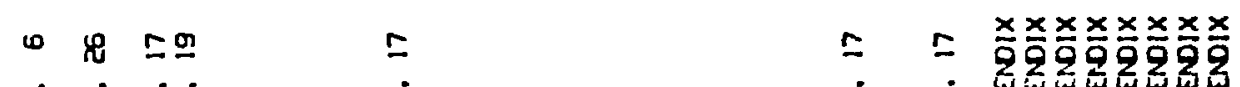
0

- R nnNOOL

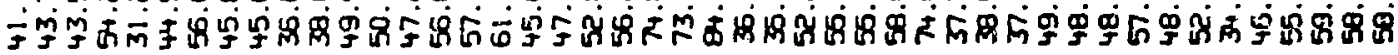

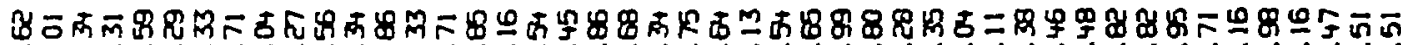

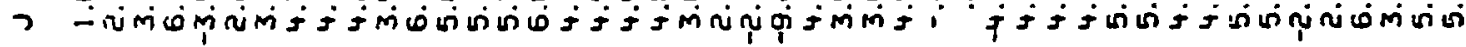

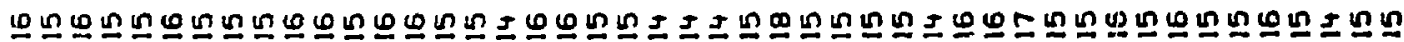

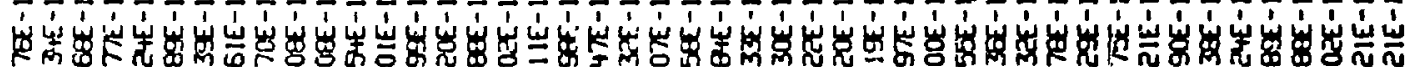

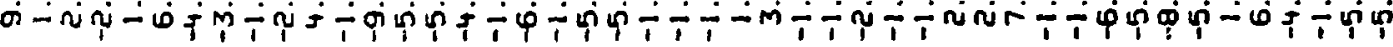

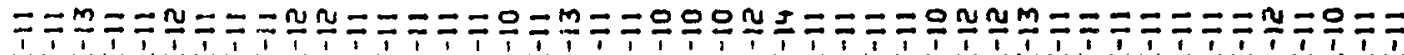

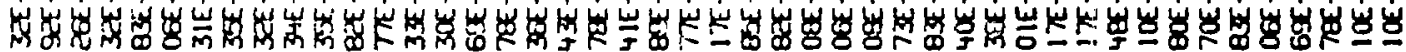

- $\div$ -

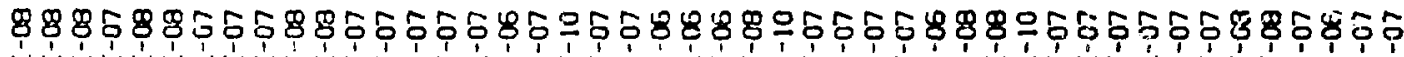

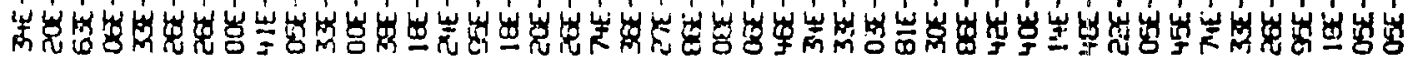

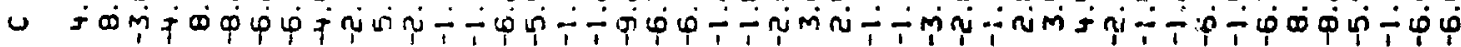

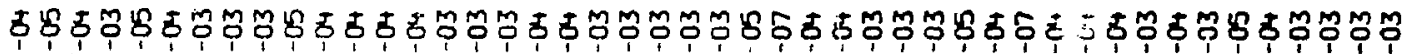

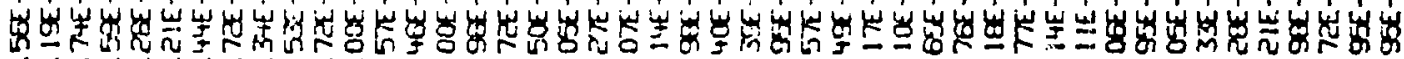

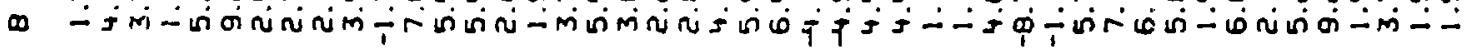

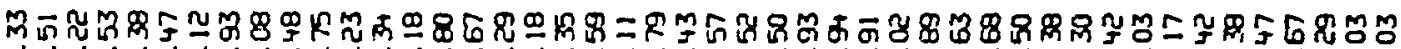

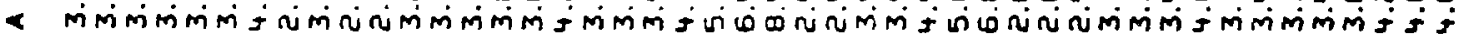

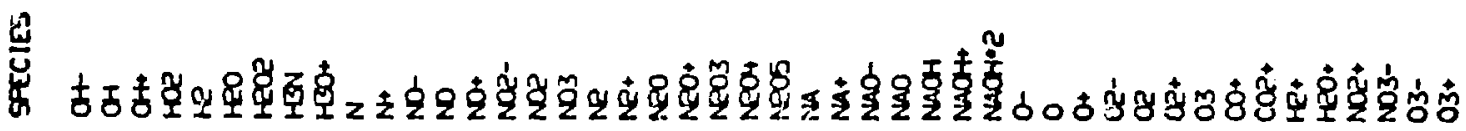




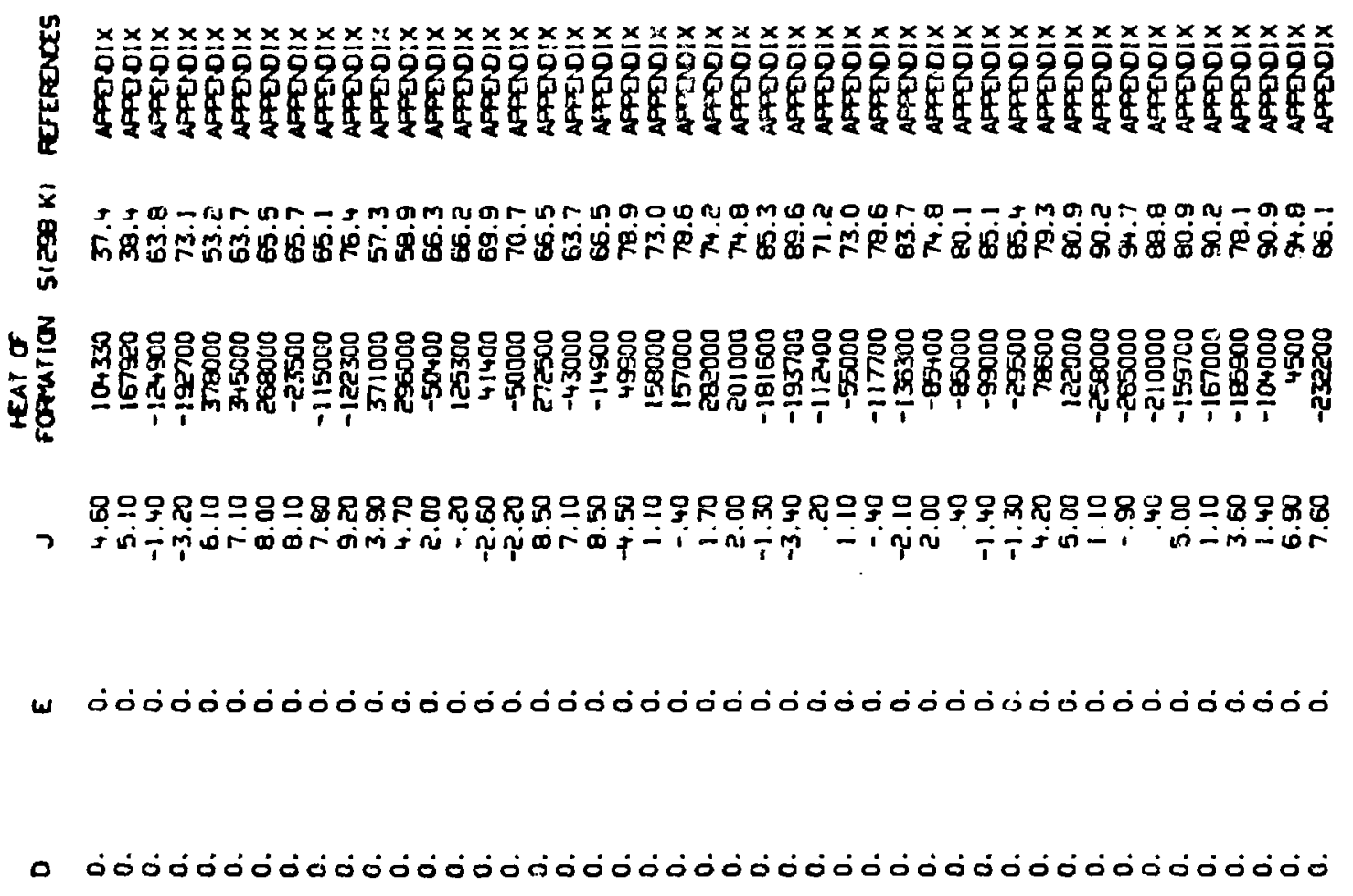

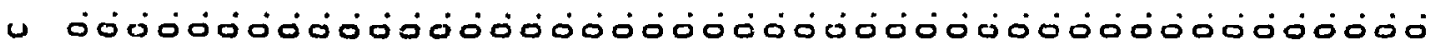

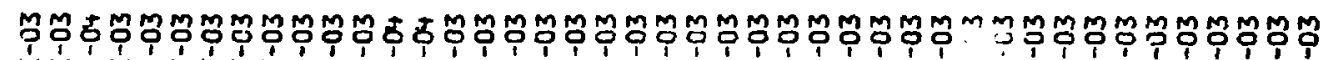

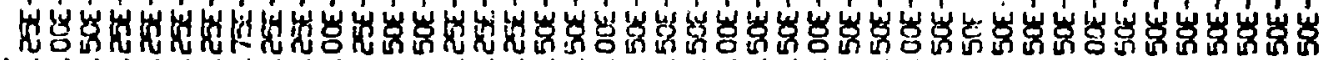

(0)

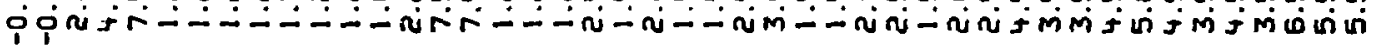

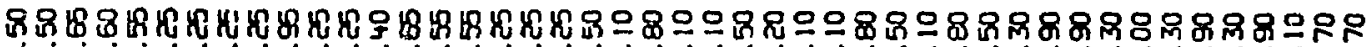
यंग

岂

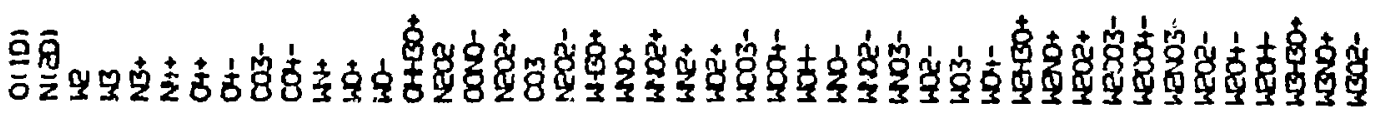



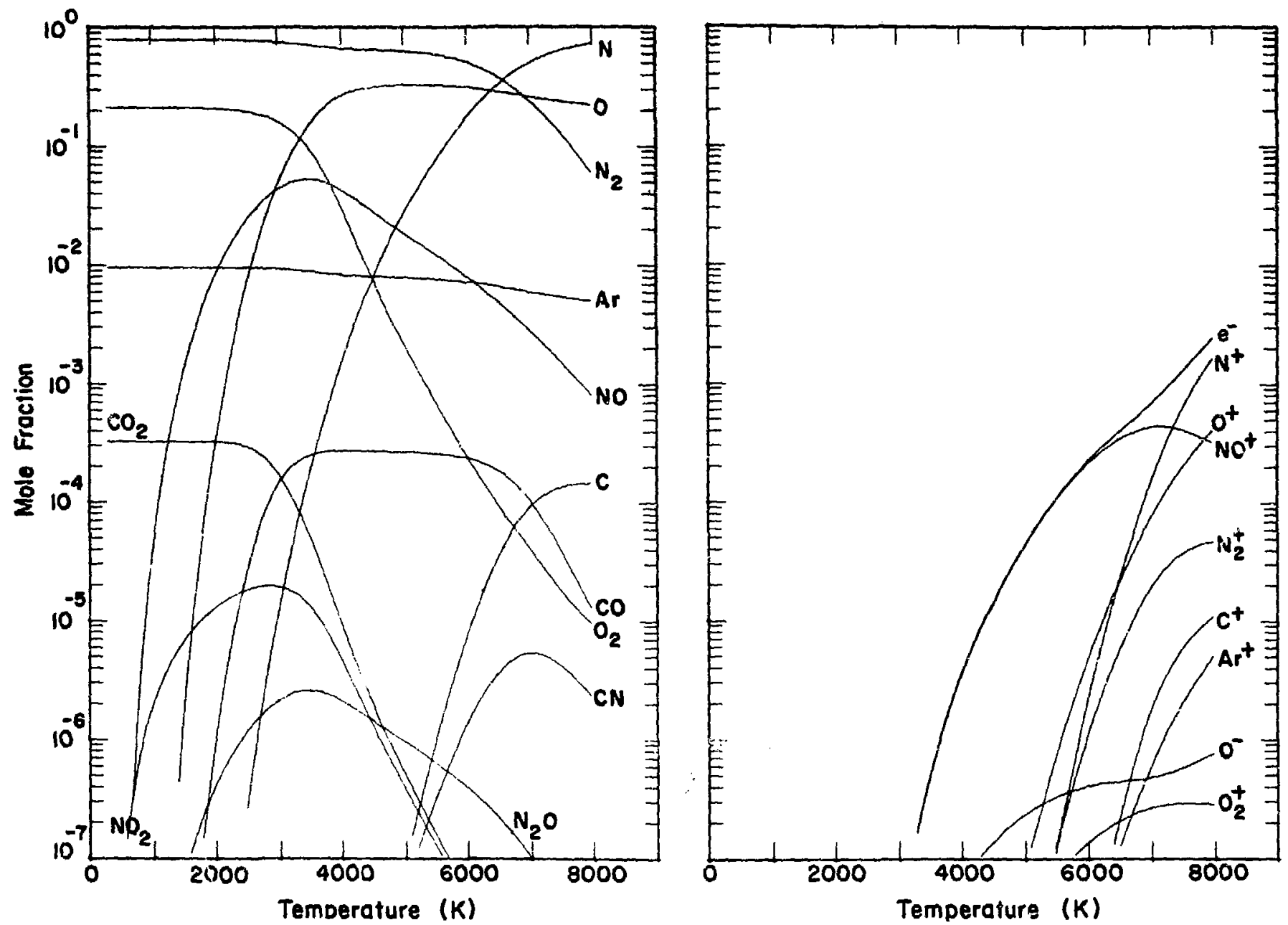

Fig. la,b. Equilibrium chemical composition of dry air as a function of temperature, for a constant pressure of 1 atmosphere. The total particle density is $7.34 \times 10^{21} / \mathrm{T} \mathrm{cm}^{-3}$ (ideal gas law). 

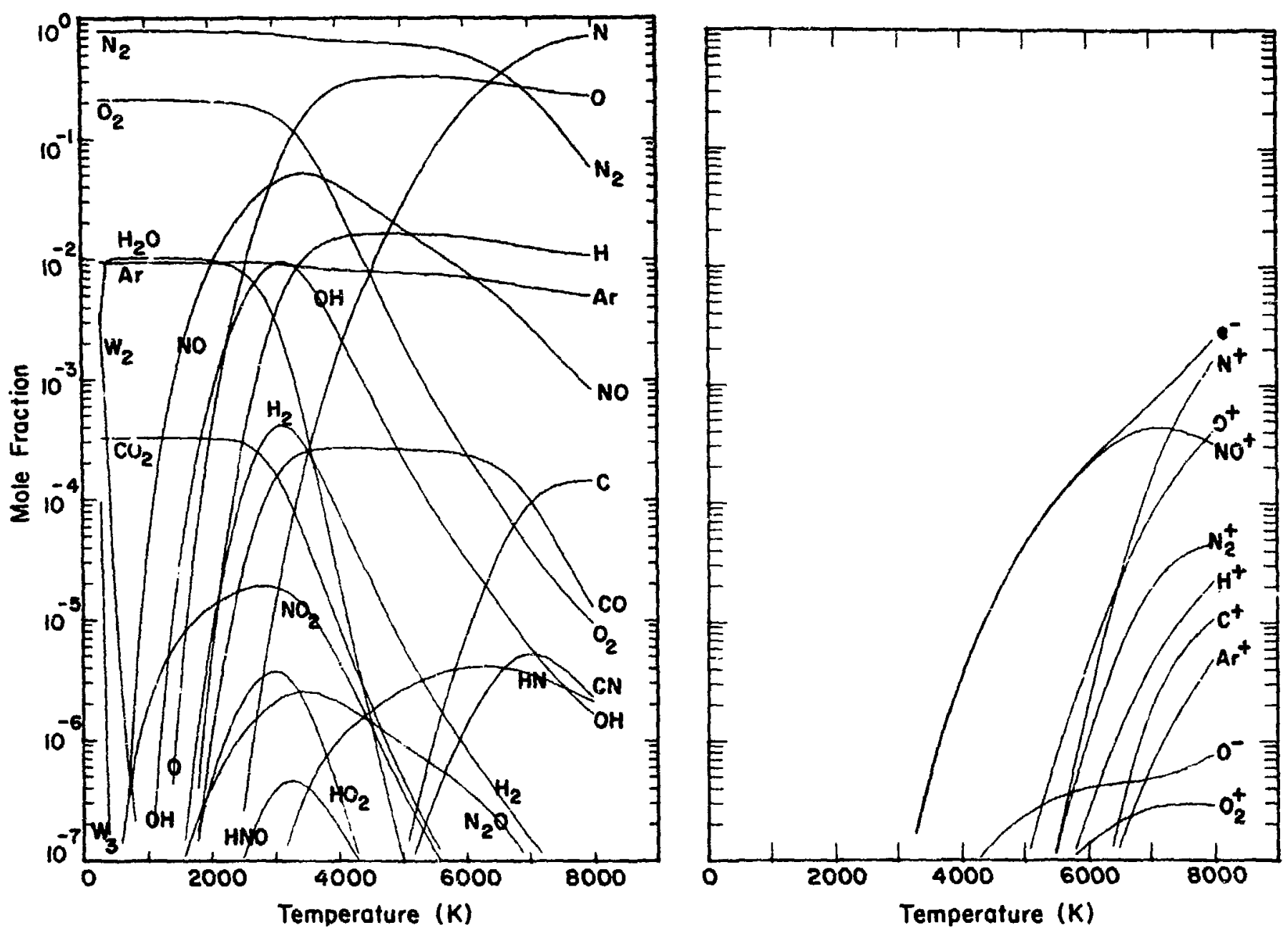

Fig. 2a,b. Equilibrium composition of moist air (1 mole $8 \mathrm{H}_{2} \mathrm{O}$ ) as a function of temperature, for constant $\mathrm{P}=1$ atmosphere. 

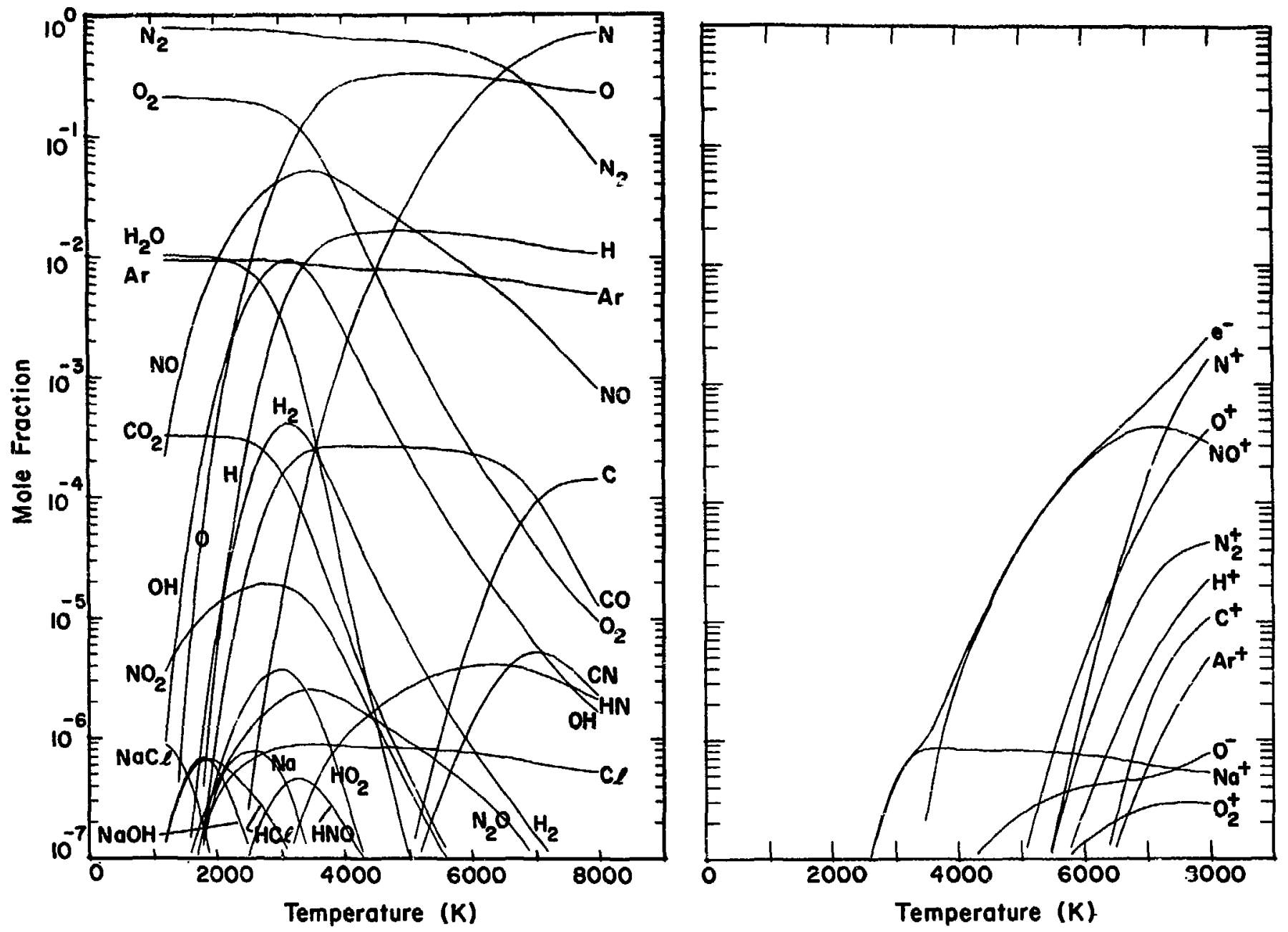

Fig. 3a,b. Equilibrium composition of salt air ( 1 mole $8 \mathrm{H}_{2} \mathrm{O}, 1 \mathrm{ppm}$ NaCl) as a function of temperature, for constant $P=1$ atmosphere. 


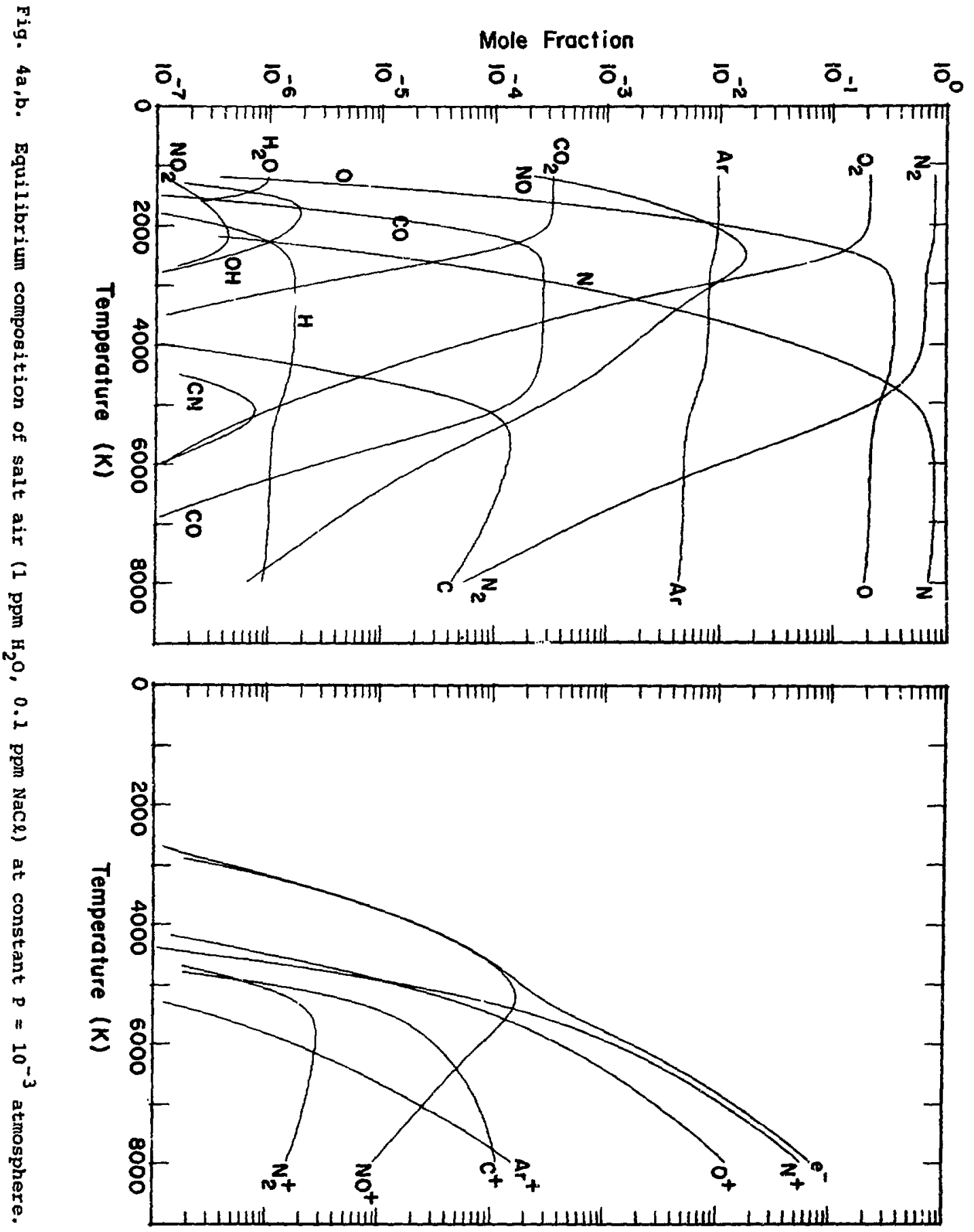



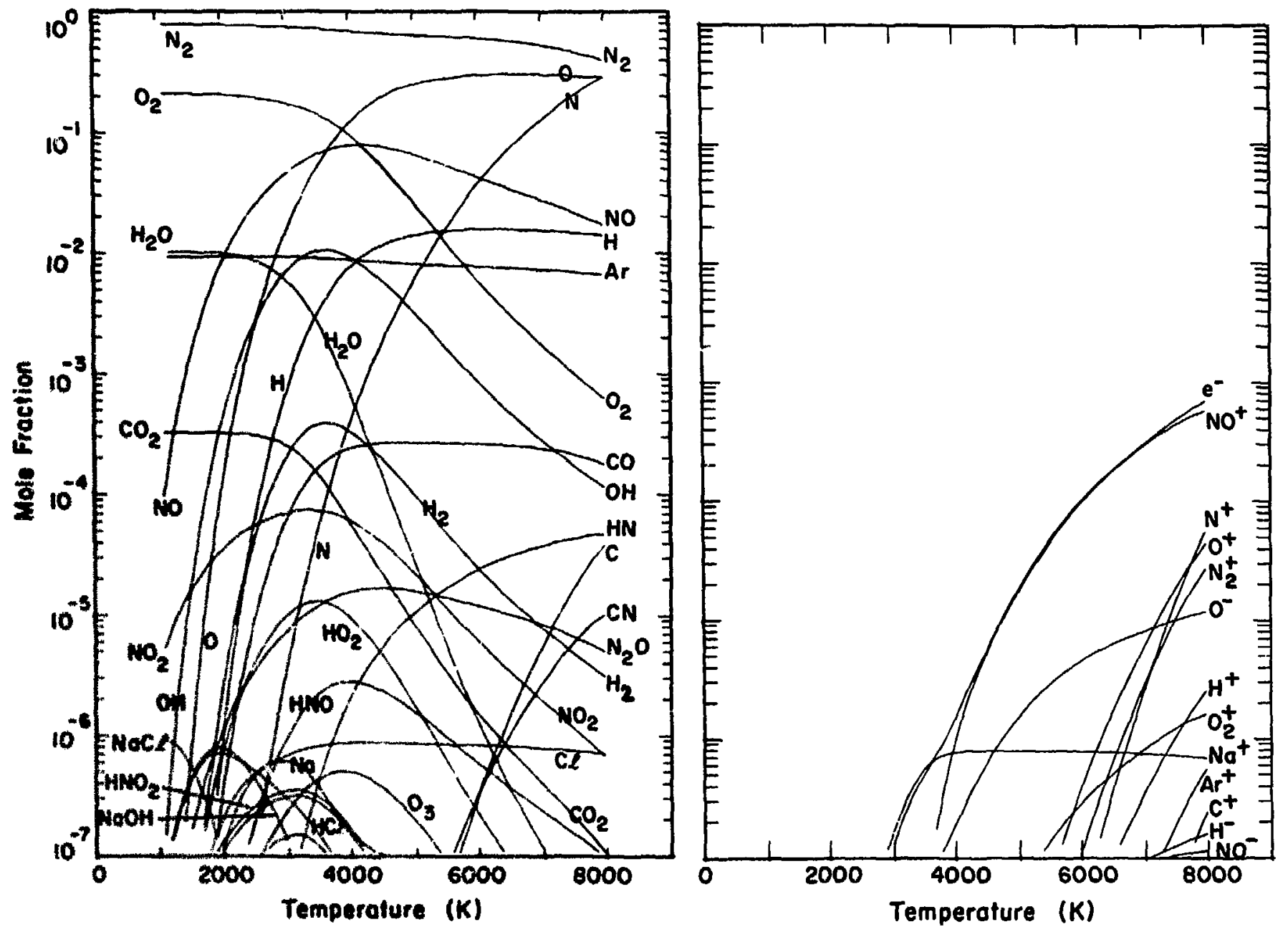

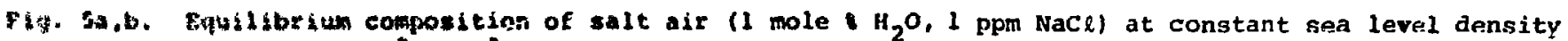
$=1.23 * 10^{-3} \mathrm{~g} / \mathrm{cm}^{3}$. 

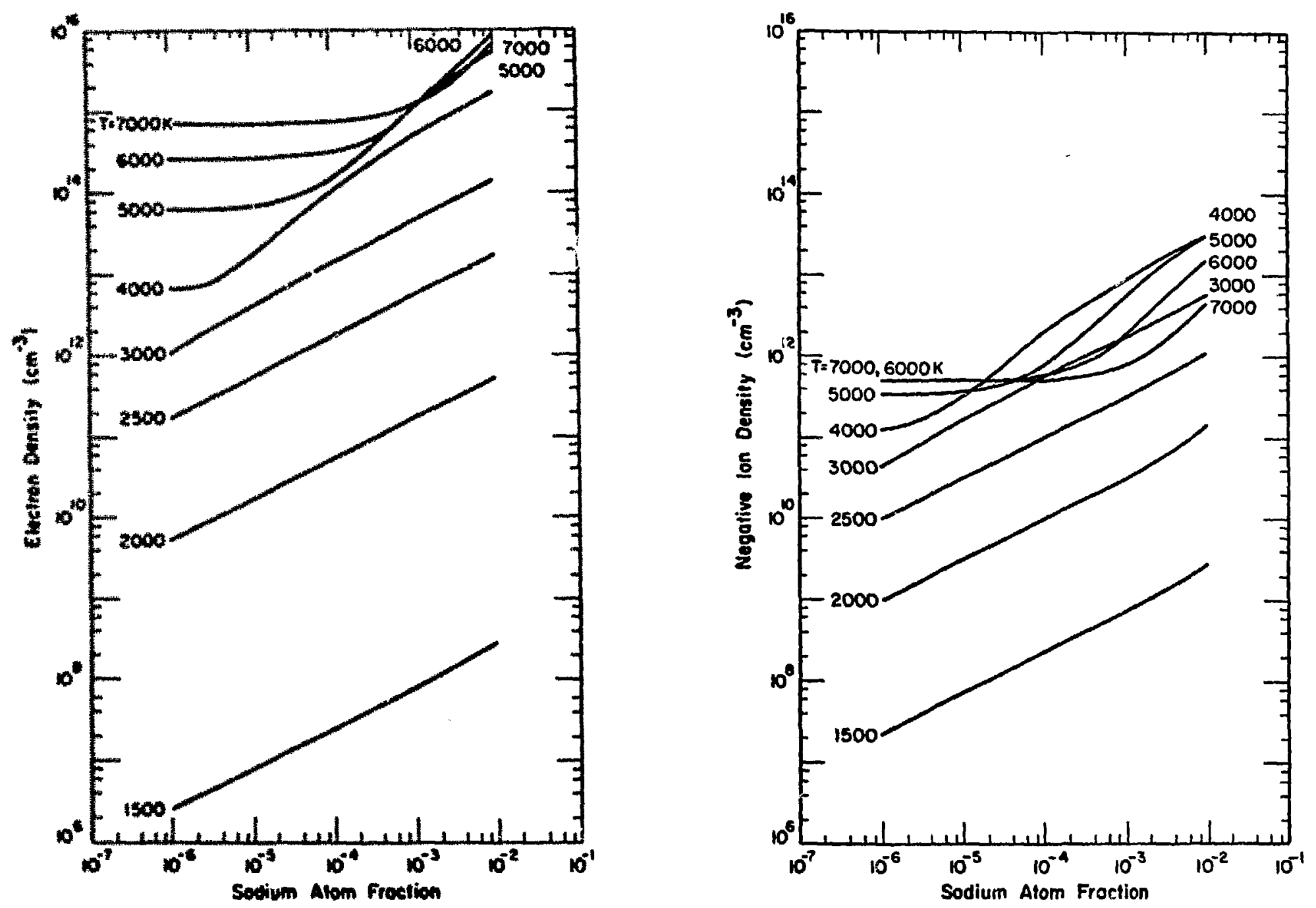

Fi9. 64.b. Electron and nagative ion number denaities in air contaminated with sodium vapor. They are plotted vs sodium atom frection for varlous velues of temperature, at constant $p=1$ atmosphere. 

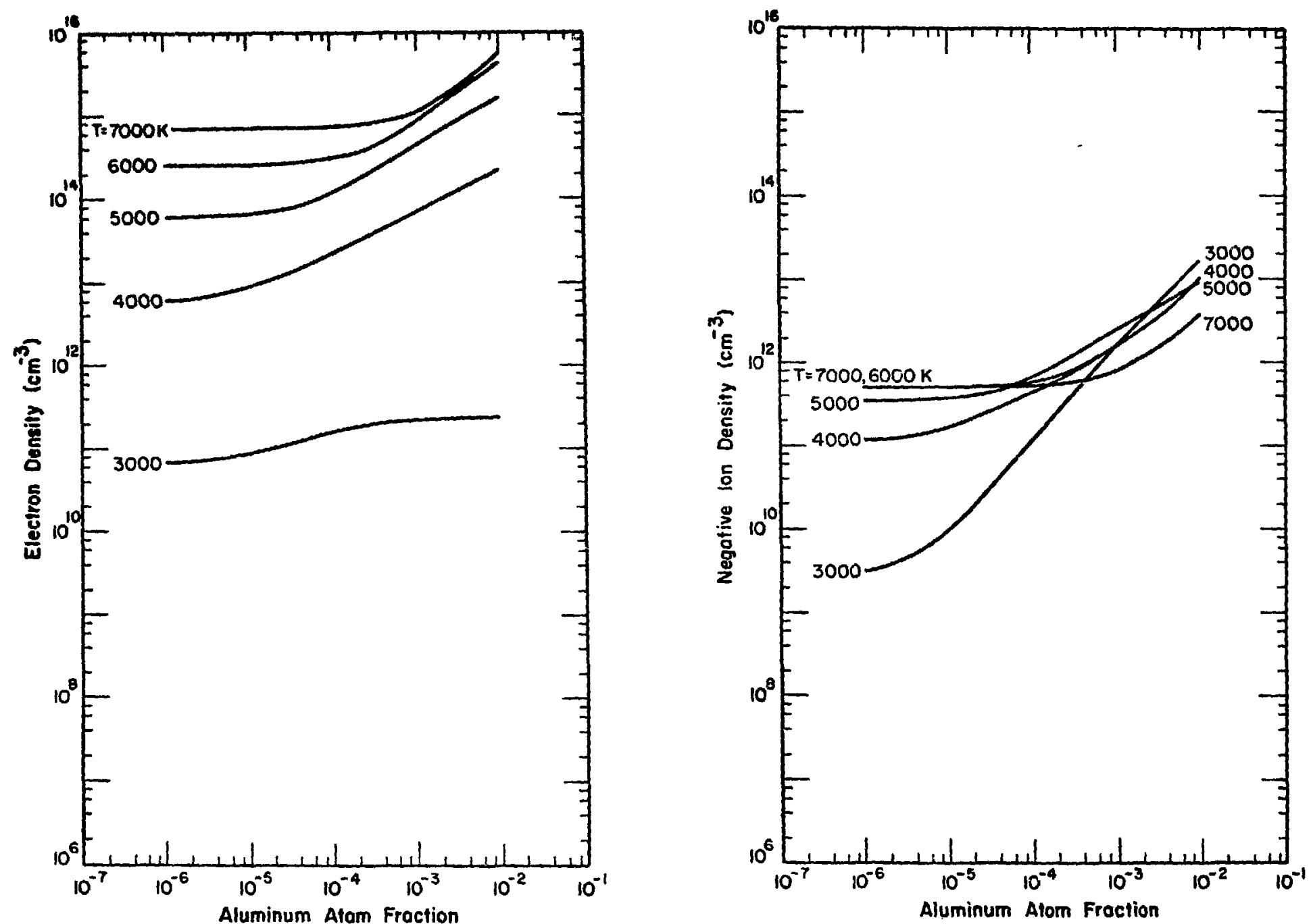

Fig. 7a,b. Electron and negative ion number densities in air contaminated with aluminum vapor. They are plotted vs aluminum atom fraction for various values of temperature, at constant $P=1$ atmosphere. 
in air over the oceans. ${ }^{36}$ Figure 3 is for a constant pressure of 1 atmosphere; Fig. 4 is for a pressure of 0.001 atmosphere;

Fig. 5 is for a constant density of $1.23 \times 10^{-3} \mathrm{~g} / \mathrm{cm}^{3}$. The main effect of the NaCl is to increase the percentage ionization at temperatures between 2000 and $5000 \mathrm{~K}$.

Figures $6(a, b)$ show electron and negative ion concentrations in air contaminated with elemental sodium. $n_{e}$ and $n_{-}$are plotted vs Na atom fraction for various values of $T$, with $P=1$ atmosphere. Figures $7(a, b)$ contain similar sets of plots for air contaminated with aluminum. The results bear on the question of enhanced ionization in a nuclear fireball produced by small quantities of vaporized bomb debris. Small quantities of sodium or aluminum can cause a very large increase in ionization. The effect of a given mole fraction of sodium is almost exactly the same as that of a similar fraction of NaCl, and electron-ion densities derived from Fig. 3b are within $10 z$ of corresponding values from Figs. $6(a, b)$.

\section{EQUILIBRIUM CONSTANTS AND REVERSE REAC-} TION RATES

For a general forward-reverse pair of chemical reactions in an ideal gas system, viz:

$$
a A+b B+\ldots \leftrightarrows \ell L+m M+\ldots
$$

the equilibrium constant in terms of number densities of reacting species is

$K_{n}=(k T)^{-\Delta \nu} \exp \left(-\Delta \bar{F}^{0} / R T\right)=\frac{n_{L}^{l} n_{M}^{m} \ldots}{n_{A}^{a} n_{B}^{b} \ldots}$

where $\Delta \bar{F}^{0}$ is the standard free energy change for the given reaction at the given tempera.ture $T, \Delta v$ is the change in the total number of moles produced in the course of "l mole" of the reaction as written

(i.e. $\Delta v=\ell+m-a-b .$. ), $k$ is Boltzmann's constant $\left(1.36 \times 10^{-22} \mathrm{~cm}^{3} \mathrm{~atm} / \mathrm{K}\right)$, and $n_{L}$ is the number of molecules of $L$ per $\mathrm{cm}^{3}$. From the fitted expression for $\bar{F}^{0}$

[Eq. (11)] the standard free energy change for the reaction is given by

$$
\begin{aligned}
\Delta \overrightarrow{\mathrm{F}}^{0} / \mathrm{RT}= & \Delta \overrightarrow{\mathrm{F}}_{0}^{0} / \mathrm{RT}+(\Delta \mathrm{A}-\Delta J)-\Delta \mathrm{A} \text { ln } \mathrm{T}-\mathrm{T} \Delta \mathrm{B} \\
& -\mathrm{T}^{2} \Delta \mathrm{C} / 2-\mathrm{T}^{3} \Delta \mathrm{D} / 3-\mathrm{T}^{4} \Delta \mathrm{E} / \mathrm{i},(20)
\end{aligned}
$$

where $\triangle A$ means $l A_{A}+m_{A_{M}}-a A_{A}-b A_{B}$, etc. This can be corchined with the previous equasion to give an expression for $k_{n}$ in terms of quantities listed in Table $I$, viz:

$$
K_{n}=Q T^{(\Delta A-\Delta V)} \exp \left(-\Delta \bar{H}_{0}^{0} / R T\right)
$$

where

$Q \equiv k^{-\Delta \nu} \exp \left(-\Delta A+\Delta J+T \Delta B+T^{2} \Delta C / 2+T^{3} \Delta D / 3+T^{4} \Delta E / 4\right)$

It would be convenient if the expression for $k_{n}$ were of the same functional form as the standard form for tabulating reaction rate coefficients, namely

$$
x=a(T / 300)^{b} e^{-c / T}
$$

(see, for example, the DNA Reaction Rate Handbook). 17 Such a functional form could be expected, at least as a reasonable approximation, since $k_{n}$ is equal to the ratio of a corresponoing pair of forward and reverse rate coefficients, both of which are of that form. That is,

$$
\begin{aligned}
k_{n} & =\kappa_{f} / k_{r} \\
& =\left(a_{f} / a_{r}\right)(T / 300)\left(b_{f}-b_{r}\right)_{\exp }\left[-\left(c_{\tilde{f}}-c_{r}\right) / T\right] \\
& \equiv a_{e q}(T / 300)\left(b_{e q}\right) \exp \left(-\Delta \tilde{H}_{0}^{0} / R T\right) .
\end{aligned}
$$

Therefore, the quantity $Q$ in Eq. (2lb) should be approximately proportional to some small power of $\mathbf{T}$.

We wish to generate reverse reaction 
rate parameters $\left(a_{x}, b_{r}, c_{r}\right)$ from known forward rate parameters $\left(a_{f}, b_{f}, c_{f}\right)$ and computed equilibrium constants. Our procedure is to sit the quantities $\mathrm{a}_{\mathrm{eq}}$ and $\mathrm{b}_{\mathrm{eg}}$ [Eq. (23)] by least squares to a set of computed values of $Q T^{(\Delta A-\Delta V)}$ [Eqs. (21)] over a specified temperature range, usually 300 - $3000 \mathrm{~K}$. The reverse rate parameter:s $a_{r}, b_{r}$, and $c_{r}$ are then derived from the $a_{f}, b_{f}, c_{f}, a_{e q}^{\prime}, b_{e q}$, and $\Delta \bar{H}_{0}^{0} / R$ by Eq. (23). Numerical values of the rate parameters will be given in the kinetics report. 5 Equation (23) makes no special note of the fact that most reactions lead to products in excited electronic, vibrational, or rotational states. A reaction process that takes reactants to products with an equilibrium population of states is usually in actuality a sequence of reactions, where the first step is the "chemical" step, taking reactants to excited products, and subsequent steps are thermalizing collisions which bring the excited products into the equilibrium population. However, for computing reverse rate coefficients--i.e. coefficients for reaction processes that convert the thermal equilibrium products back to the thermal equilibrium reactants--detailed descriptions of the stepwise processes are usually unnecessary, and Eq. (23) gives correct results.

For example, congider the dissociative recombination reaction.

$$
\mathrm{o}_{2}^{+}+\mathrm{e} \frac{\mathrm{k}_{\mathrm{f}}}{\mathrm{k}_{\mathrm{r}}} \mathrm{o}+0
$$

The first step is known to lead to an excitad metastable of ${ }^{\prime}$ ) atom, subsequently convurted to o ( ${ }^{3}$ p) by collisional deexcitation. Tho overall process can be described as consisting of the two steps

$$
o_{2}^{+}+c \frac{k_{1 f}}{k_{1 r}} o(t)+o
$$

$$
o\left({ }^{l} D\right)+M \frac{k_{2 f}}{k_{2 r}} o+M
$$

where $M$ is the moderator. We wish to calculate the rate coefficient $k_{r}$ for the reverse of the overall process [Eq. (24)], given the measured coefficient $k_{f} \equiv k_{1 f}$ of the forward reaction.

The rate equations for the $\mathrm{O}_{2}^{+}$and $O\left(^{1} D\right)$ concentrations are

$\frac{d\left[c_{2}^{+}\right]}{d t}=-k_{1 f}\left[O_{2}^{+}\right][e]+k_{1 r}\left[O\left({ }^{1} D\right)\right][0]$,

and

$$
\begin{aligned}
\frac{d\left[O\left(^{1} D\right)\right]}{d t}= & k_{1 f}\left[O_{2}^{+}\right][e]-k_{2 f}\left[O\left(^{1} D\right)\right][M] \\
& +k_{2 r}[O][M]-k_{1 r}\left[O\left(^{1} D\right)[O]\right.
\end{aligned}
$$

where square brackets denote concentrations. Now let us invoke the steady state assumption $d\left[o\left({ }^{1} D\right)\right] / d t \approx 0$, which is equivalent to assuming that it is much smaller than any of the four separate terms on the right-hand side of Eq. (28). Then we can solve for $\left|O\left(^{l} D\right)\right|$, and substitute in Eq. (27) to obtain

$$
\begin{gathered}
\frac{d\left[O_{2}^{+}\right\rfloor}{d t}=\left\{-k_{1 f} k_{2 f}\left[O_{2}^{+}\right][e]+k_{1 r} k_{2 x}[O]^{2}\right\} \times \\
{[M] /\left\{k_{1 x}[O]+k_{2 E}[M]\right\}}
\end{gathered}
$$

Now $k_{2 f}(M)$ is almost certainly much larger than $k_{1 r}(0)$. If this is true, and if we define the equilibrium constants $k_{1} \equiv k_{1 f} / k_{1 r}$ and $k_{2} \equiv k_{2 f} / k_{25}$, then Eq. (29) simplifies to

$\frac{d\left(0_{2}^{+}\right)}{d t}=-k_{16}\left(0_{2}^{+}\right)(e]+\left(k_{1 f} / k_{1} k_{2}\right)[0]^{2}$

and 
This is exactly the rate equation corresponding to the overall reaction as described by Eq. (24), and $k_{r}=k_{1 f} / k_{1} k_{2}$ is the same reverse rate coefficient for that process as we would have obtained directly with Eq. (23), without considering the stepwise reactions (25) and (26).

The above arguments rest on the assumption that $k_{2 f}[M]$ is much larger than $k_{1 r}[0]$. and the equivalent assumption can be made for most reactions. For the example cited, at $298 \mathrm{~K}, \mathrm{k}_{1 \mathrm{f}}=2 . \times 10^{-7} \mathrm{~cm}^{3} / \mathrm{s}$, $k_{2 f} \cong 7 . \times 10^{-11} \mathrm{~cm}^{3} / \mathrm{s}$ (Ref. 17). $k_{1}=10^{90}, k_{1 r}=k_{1 E} / k_{1}=2 . \times 10^{-97} \mathrm{~cm}^{3} / 5$. and $[M] \geq[0]$, so that $k_{2 f}[M]$ is indeed $>k_{1 r}[0]$.

Nevertheless, despite our conclusion that we can compute most overall reverse rate coefficients correctly with Eq. (23). it is frequent ly necessary in kinetias problems to consider detailed stepwise processes as in Eqs. (25) and (26). In particular, for stratospheric problems and fireball problems, it is necessary to follow concentrations of metastable atoms $O\left({ }^{1} D\right)$ and $N\left({ }^{2} D\right)$. For this reason we have included thermodynamic functions for these two specieg in the Appendix of this report.

\section{APPENDIX}

ASSUMED MOLECULAR STRUCTURES AND OTHER ASSUMPTIONS LEADING TO

\section{ESTIMATED THERMODYNAMIC PARAMETERS}

This appendix describes our assumptions leading to estimated thermodynamic parameters for some of the complex molecules and ions listed in Table $I$. The heat of formation values are in every case based on some experimental information. Most of the entropy estimates, on the other hand, are based on assumptions about moleculax structures, moments of inertia, and low-frequency vibrational modes, which are more or less wild. In most instances the assumed structures and molecular dinensions will be defined, as will the ground state degeneracies $\mathrm{g}_{0}$, the symmetry numbers 0 , molecular weights $M$, moment of inertia products abc, and the $n_{t+b}$ lowest vibrational frequencies $w_{i}$. The heats of formation $\bar{H}_{0}^{0}$ and the cal- culated $\bar{c}_{p^{\prime}} \vec{s}_{2 j 8}^{0}$, and parameters $A-J$ will also be given.

If we comnit a factor-of-four error in estimating abc, then we commit an error of only $\mp 1.4 \mathrm{cal} / \mathrm{deg}$ mole in $\bar{s}_{\text {ror }}^{0}(298 \mathrm{k})$. On the other hand, the error in $\bar{S}_{\mathrm{vib}}^{0}(298 \mathrm{~K})$ may in some cases be rather large. The estimated uncertainties in the $\vec{H}_{0}^{0}$ and $\vec{S}_{298}^{0}$ will be indicated.

The order of listing of the species is: $\mathrm{CO}^{+}, \mathrm{CO}_{2}^{+}, \mathrm{H}_{2}^{+}, \mathrm{H}_{2} \mathrm{O}^{+}, \mathrm{No}_{2}^{+}, \mathrm{No}_{3}^{-}, \mathrm{O}_{3}^{-}, \mathrm{O}_{3}^{+}, \mathrm{O}\left({ }^{+} \mathrm{D}\right)$, $\mathrm{N}\left({ }^{2} \mathrm{O}\right),\left(\mathrm{H}_{2} \mathrm{O}\right)_{2},\left(\mathrm{H}_{2} \mathrm{O}\right)_{3}, \mathrm{~N}_{3}^{+}, \mathrm{N}_{4}^{+}, \mathrm{O}_{4}^{+}, \mathrm{O}_{4}^{-}, \mathrm{CO}_{3}^{-}$, $\mathrm{CO}_{4}^{-}, \mathrm{N}^{+} \cdot \mathrm{H}_{2} \mathrm{O}, \mathrm{O}^{+} \cdot \mathrm{H}_{2} \mathrm{O}, \mathrm{OH} \cdot \mathrm{H}_{3} \mathrm{O}^{+},(\mathrm{NO})_{2}, \mathrm{O}_{2}^{-} \cdot \mathrm{NO}$, $\mathrm{O}_{2}^{+} \cdot \mathrm{N}_{2}, \mathrm{O}_{2}^{-} \cdot \mathrm{N}_{2}, \mathrm{CO}_{3}$, and mincellaneous hydrated polyatomic icns (Table AI). The ordering is roughly one of increasing uncertainty. 
$\mathrm{CO}^{+}$

Moment of inertia, $\bar{C}_{p}^{0}$, and coefficients $A$ through $E$ assumed to be the same as for $c o$. Ground state degeneracy $g_{0}=2$.

$\overline{\mathrm{H}}_{0}^{0}=\overline{\mathrm{H}}_{0}^{0}(\mathrm{CO})+322.79$

$=+296.0 \mathrm{kcal}$ mole $\mathrm{e}^{-1}$ (Ref.17,18)

$\bar{s}_{298}^{0}=\bar{s}_{298}^{0}(\mathrm{CO})+R \ln 2$

$=48.59 \mathrm{cal} \mathrm{deg}^{-1} \mathrm{~mole}^{-1}$

$J=J(C O)+\ln 2=5.95$

$\mathrm{CO}_{2}^{+}$

Moment of inertia, $\overline{\mathrm{C}}_{\mathrm{p}^{\prime}}^{0}$, and coefficients $A$

through $\mathrm{E}$ assumed to be the same as for $\mathrm{CO}_{2}$.

Ground state degeneracy $g_{0}=2$.

$\overline{\mathrm{H}}_{0}^{0}=\overrightarrow{\mathrm{H}}_{0}^{0}\left(\mathrm{CO}_{2}\right)+316.33$

$=+223.5 \mathrm{kcal}^{\mathrm{mole}} \mathrm{e}^{-1}(\mathrm{Ref} .17,18)$

$\bar{s}_{298}^{0}=\bar{s}_{298}^{0}\left(\mathrm{CO}_{2}\right)+R \ln 2$

$=52.7 \mathrm{cal} \mathrm{deg}^{-1} \mathrm{~mole}^{-1}$

$J=J\left(\mathrm{CO}_{2}\right)+\ln 2=5.71$

$\mathrm{H}_{2}^{+}$

$\overline{\bar{C}_{p}^{0}}$ and coefficients $A$ through $E$ assumed to be the same as for $\mathrm{H}_{2}$. Internuclear distance $r=1.06 \AA^{18}$ compared to $0.7416 \AA$ for $\mathrm{H}_{2} \cdot \mathrm{g}_{0}=2$.

$\overline{\mathrm{H}}_{0}^{0}=+355.7 \mathrm{kcal} \mathrm{mole}^{-1}$ (Ref.17,18)

$\bar{s}_{298}^{0}=\bar{s}_{298}^{0}\left(\mathrm{H}_{2}\right)+2.80=34.01 \mathrm{cal} \mathrm{deg}^{-1} \mathrm{~mole}^{-1}$

$J=-2.16$

$\mathrm{H}_{2} \mathrm{O}^{+}$

Moments of inertia, $\bar{c}_{p}^{0}$ and $A$ through $E$ assumed to be the same as for $\mathrm{H}_{2} \mathrm{O} . \mathrm{g}_{0}=2$. $\overline{\mathrm{H}}_{\mathrm{O}}^{0}=+233.9 \mathrm{kcal}$ mole $\mathrm{e}^{-1}$ (Ref.17,18)

$\bar{s}_{298}^{0}=46.48 \mathrm{cal} \mathrm{deg}^{-1} \mathrm{~mole}^{-1}$

$J=2.98$

$\underline{\mathrm{NO}_{2}^{+}}$

Moments of inertia, $\bar{C}_{p}^{0}$ and $A$ through $E$ assumed to be the same as for $\mathrm{NO}_{2} \cdot g_{0}=1$, compared to 2 for $\mathrm{NO}_{2}$.

$\overline{\mathrm{H}}_{0}^{0}=+234.2 \mathrm{kcal} \mathrm{mole}^{-1}$ (Ref.17,18)

$\vec{s}_{298}^{0}=55.96 \mathrm{cal} \mathrm{deg}^{-1} \mathrm{~mole}^{-1}$

$\mathrm{J}=6.16$
$\mathrm{NO}_{3}^{-}$

Moments of inertia, $\overrightarrow{\mathrm{C}}_{\mathrm{p}}^{0}$ and $\mathrm{A}$ through $\mathrm{E}$ same as for $\mathrm{NO}_{3} \cdot g_{0}=1$, compared to 2 for $\mathrm{NO}_{3}$. Electron affinity of $\mathrm{NO}_{3}=3.7 \mathrm{ev} .19$

$\overline{\mathrm{H}}_{0}^{0}=-66.7 \mathrm{kcal}$ mole $\mathrm{e}^{-1}$

$\bar{s}_{298}^{0}=59.0 \mathrm{cal} \mathrm{deg}^{-1} \mathrm{~mole}^{-1}$

$\mathrm{J}=3.47$

$\underline{\mathrm{O}_{3}^{-}}$

Moments of inertia, $\overline{\mathrm{C}}_{\mathrm{p}}^{0}$ and $\mathrm{A}$ through $\mathrm{E}$ same as for $o_{3}, g_{0}=2$.

$\overline{\mathrm{H}} \mathrm{8}=-13 \mathrm{kcal}_{\mathrm{mole}}^{-1}$ (Ref.17)

$\bar{S}_{298}^{0}=58.46 \mathrm{cal} \mathrm{deg}^{-1} \mathrm{~mole}^{-1}$

$\mathrm{J}=5.51$

$\mathrm{O}_{3}^{+}$

Moments of inertia, $\vec{C}_{p}^{0}$ and $A$ through $E$ same as for $\mathrm{O}_{3}, g_{0}=2$.

$\overline{\mathrm{H}}_{0}^{0}=+329.9 \mathrm{kcal} \mathrm{mole}^{-1}$ (Ref.17)

$\bar{s}_{298}^{0}=58.46 \mathrm{cal} \mathrm{deg}^{-1} \mathrm{~mole}^{-1}$

$\mathrm{J}=5.51$
$O\left(2^{1} D_{2}\right)$

$\overline{\overline{\mathrm{H}}_{0}^{0}}=104.33 \mathrm{kcal} \mathrm{mole}^{-1}$ (see JANAF $^{6}$ )

$\bar{s}_{298}^{0}=37.45 \mathrm{cal} \mathrm{deg}^{-1} \mathrm{~mole}^{-1}$

$\overline{\mathrm{C}}_{\mathrm{p}}^{\mathrm{0}}(298 \mathrm{~K})=4.97 \mathrm{cal}^{\mathrm{deg}} \mathrm{deg}^{-1} \mathrm{~mole}^{-1}$

$A=2.5, B=C=D=E=O$

$\mathrm{J}=4.60$

$\frac{\mathrm{N}\left(2^{2} \mathrm{D}_{3 / 2,5 / 2}\right)}{\overline{\mathrm{H}^{0}}=167,92 \mathrm{~s}}$

$\overline{\mathrm{H}_{0}^{0}}=167.92 \mathrm{kcal} \mathrm{mole} \mathrm{e}^{-1}$ (see $\mathrm{JANhF}^{6}$ )

$\bar{s}_{298}^{0}=38.43 \mathrm{cal} \mathrm{deg}^{-1} \mathrm{~mole}^{-1}$

$\bar{C}_{p}^{0}(298 \mathrm{~K})=4.97 \mathrm{cal}_{\mathrm{deg}}^{-1} \mathrm{~mole}^{-1}$

$A=2.5, B=C=D=E=0$

$J=5.09$ 
Water dimer $\left(\mathrm{H}_{2}{ }^{\mathrm{O}}\right)_{2}$

Molecular weight $M=36$. $n_{\text {atoms }}=6$. Multiplicity $g_{0}=1$. Heat of dimerization assumed to be $-10.7 \mathrm{kcal}$ mole $\mathrm{e}^{-1}$ (from heat of vaporization). Assumed structure: planar. $0-H^{\prime}$ distance taken to be $1.5 \AA$, consistent with assumed heat of dimerization. Symmetry number $\sigma=2$. Important low-frequency modes $n_{t+b}=3, w=50,200,200 \mathrm{~cm}^{-1}$.

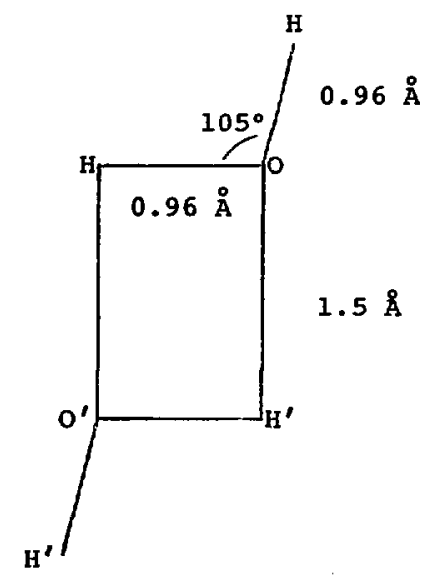

Moments of inertia:

$$
\begin{aligned}
& a=2 \times 10^{-40} \mathrm{~g} \mathrm{~cm}^{2} \\
& b=9.5 \times 10^{-39} \mathrm{~g} \mathrm{~cm}^{2} \\
& \text { c }=9.7 \times 10^{-39} \mathrm{~g} \mathrm{~cm}^{2} \\
& \text { abc }= \pm .84 \times 10^{-116} \mathrm{~g}^{3} \mathrm{~cm}^{6} \\
& \overrightarrow{\mathrm{H}}_{0}^{0}=-124.9 \mathrm{kcal} \text { mole }{ }^{-1} \mp 3
\end{aligned}
$$

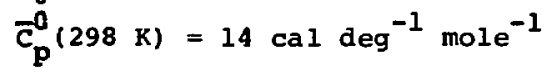

$$
\begin{aligned}
& \mathrm{A}=5.65, \mathrm{~B}=0.00225, \mathrm{C}=\mathrm{D}=\mathrm{E}=0 \\
& \bar{s}_{\text {trans }}^{0}(298 \mathrm{~K})=36.66 \mathrm{cal} \mathrm{deg}^{-1} \mathrm{~mole}^{-1} \\
& \bar{S}_{\text {rot }}^{0}(298 \mathrm{~K})=18.39 \mathrm{cal} \mathrm{deg}^{-1} \mathrm{~mole}^{-1} \\
& \vec{s}_{\text {vib }}^{0}(298 \mathrm{~K})=8.7 \mathrm{cal} \mathrm{deg}^{-1} \mathrm{~mole}^{-1} \\
& \bar{s}_{298}^{0}=63.7 \mp 3 \mathrm{cal} \mathrm{\textrm {deg } ^ { - 1 } \mathrm { mole }}-1 \\
& \mathrm{~J}=-1.4
\end{aligned}
$$

Water trimer $\left(\mathrm{H}_{2} \mathrm{O}\right)_{3}$

$M=54 . \quad n_{\text {atoms }}=9 . \quad g_{0}=1$. Assumed moment of inertia product $a b c=9.4 \times 10^{-115} \mathrm{~g}^{3} \mathrm{~cm}^{6} . \quad \sigma=1$.

$\mathrm{n}_{t+b}=5 . \omega=20,20,100,100,100 \mathrm{~cm}^{-1}$.

$\widetilde{\mathrm{H}}_{0}^{0}=-192.7 \mathrm{kcal} \mathrm{mole}^{-1} \mp_{4}$

$\bar{C}_{\mathrm{p}}^{0}(298 \mathrm{~K})=\cdot 18 \mathrm{cal} \mathrm{deg}^{-1} \mathrm{~mole}^{-1}$

$\mathrm{A}=6.6, \mathrm{~B}=+0.004, \mathrm{C}=\mathrm{D}=\mathrm{E}=0$

$\bar{s}_{\text {trans }}^{0}(298 \mathrm{~K})=37.87 \mathrm{cal} \mathrm{deg}^{-1} \mathrm{~mole}^{-1}$

$\overrightarrow{\mathrm{S}}_{\text {rot }}^{0}(298 \mathrm{~K})=23.68 \mathrm{cal} \mathrm{aeg}^{-1} \mathrm{~mole}^{-1}$

$\overline{\mathrm{S}}_{\mathrm{vib}}^{0}(298 \mathrm{~K})=11.7 \mathrm{cal} \mathrm{deg}^{-1} \mathrm{~mole}^{-1}$

$\bar{s}_{298}^{0}=73.2 \mp 10 \mathrm{cal} \mathrm{deg}^{-1} \mathrm{~mole}^{-1}$

$J=-3.2$

$\frac{\mathrm{N}_{3}^{+}}{\mathrm{M}=42 .} \quad \mathrm{n}_{\text {atoms }}=3 . \quad g_{0}=1$.

Assumed structure: equilateral triangle resonance hybrid. $\sigma=6$. Bond lengths $1.32 \stackrel{\circ}{\AA} . n_{t+b}=0$.

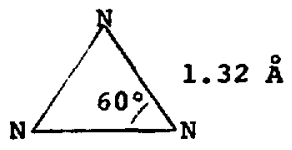

Moments of inertia:

$$
\begin{aligned}
& a=b=2.0 \times 10^{-39} \mathrm{~g} \mathrm{~cm}^{2} \\
& c=4.0 \times 10^{-39} \mathrm{~g} \mathrm{~cm} \\
& a b c=1.65 \times 10^{-116} \mathrm{~g}^{3} \mathrm{~cm}^{6}
\end{aligned}
$$

$\overrightarrow{\mathrm{H}}_{0}^{0} \leq 378 \mathrm{kcal}$ mole ${ }^{-1}$ (Ref. 20)

$\bar{c}_{\mathrm{p}}^{0}(298 \mathrm{~K})=8 \cdot \mathrm{cal} \mathrm{deg}^{-1} \mathrm{~mole}^{-1}$

$A=3.55, B=0.00075, C=D=E=0$

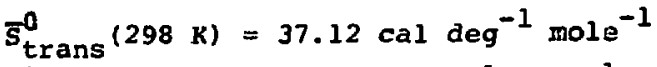

$\bar{s}_{\text {rot }}^{0}(298 \mathrm{~K})=16.10 \mathrm{cal} \mathrm{deg}^{-1} \mathrm{~mole}^{-1}$

$\overline{\mathbf{s}}_{\mathrm{vib}}^{0}(298 \mathrm{~K})=0$

$\bar{s}_{298}^{0}=53.2 \mathrm{cal} \mathrm{deg}^{-1} \mathrm{~mole}^{-1} \mp 2$

$J=6.10$ 
$\underline{\mathrm{N}_{4}^{+}}$

$M=56 . n_{\text {atoms }}=4, g_{0}=2$. Assumed structure: square resonance hybrid. $\sigma=8$. Bond lengths $1.44 \AA . n_{t+b}=1 . \omega=20 \mathrm{~cm}^{-1}$.

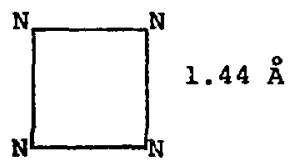

Moments of indrtia:

$$
\begin{aligned}
& a=b=4.8 \times 10^{-39} \mathrm{~g} \mathrm{~cm}^{2} \\
& c=9.6 \times 10^{-39} \mathrm{~g} \mathrm{~cm}^{2}
\end{aligned}
$$$$
a b c=2.25 \times 10^{-115} \mathrm{~g}^{3} \mathrm{~cm}^{6}
$$$$
\overline{\mathrm{H}}_{0}^{0} \leq \text { 345. kcal mole } \mathrm{k}^{-1} \text { (Ref. 20) }
$$$$
\bar{C}_{p}^{0}(298 \mathrm{~K})=10 \cdot \mathrm{cal} \mathrm{deg}^{-1} \mathrm{~mole}^{-1}
$$$$
\mathrm{A}=4.25, \mathrm{~B}=0.00125, \mathrm{C}=\mathrm{D}=\mathrm{E}=\mathrm{O}
$$$$
\vec{s}_{\text {trans }}^{0}(298 \mathrm{~K})=39.35 \mathrm{cal} \mathrm{deg}^{-1} \mathrm{~mole}^{-1}
$$

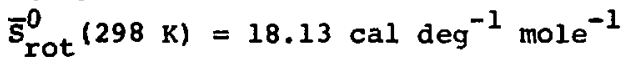$$
\overline{\mathrm{s}}_{\mathrm{Vib}}^{0}(298 \mathrm{~K})=6.6 \mathrm{cal}_{\mathrm{deg}}{ }^{-1} \mathrm{~mole}^{-1}
$$

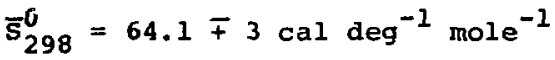

$J=7.1$

$\underline{o_{4}^{+}}$

$M=64 . n_{\text {atoms }}=4, g_{0}=2$. Assumed structure: square resonance hybrid, $\sigma=8$. Bond lengths $1.6 \AA . n_{t+b}=1 . \omega=20 \mathrm{~cm}^{-1}$.

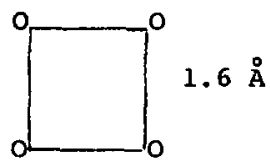

Moments of inertia:

$$
\begin{aligned}
& a=b=6.8 \times 10^{-39} \mathrm{~g} \mathrm{~cm}^{2} \\
& c=1.36 \times 10^{-38} \mathrm{~g} \mathrm{~cm}^{2} \\
& a b c=6.3 \times 10^{-115 \mathrm{~g}^{3} \mathrm{~cm}^{6}}
\end{aligned}
$$$$
\overline{\mathrm{H}}_{0}^{0}=268, \mp 2 \mathrm{kcal} \text { mole } \mathrm{e}^{-1} \text { (Ref. 21, 22) }
$$$$
\bar{c}_{p}^{0}(298 \mathrm{~K})=10 . \mathrm{cal} \mathrm{deg}^{-1} \mathrm{~mole}^{-1}
$$

$\mathrm{A}=4.25, \mathrm{~B}=0.00125, \mathrm{C}=\mathrm{D}=\mathrm{E}=0$

$\overrightarrow{\mathbf{s}}_{\text {trans }}^{0}(298 \mathrm{~K})=39.75 \mathrm{cal} \mathrm{deg}^{-1} \mathrm{~mole}^{-1}$

$\bar{S}_{\text {IOt }}^{0}(298 \mathrm{~K})=19.15{\mathrm{cal} \mathrm{deg}^{-1} \mathrm{~mole}}^{-1}$

$\overline{\mathrm{s}}_{\mathrm{vib}}^{0}(29 \mathrm{kK})=6.6 \mathrm{cal} \mathrm{deg}^{-1} \mathrm{~mole}^{-1}$

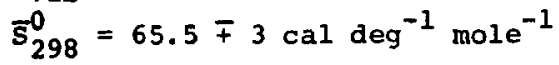

$J=8.0$ $\underline{0_{4}^{-}}$

$\mathrm{M}=64 . \mathrm{n}_{\text {atoms }}=4 . \mathrm{g}_{0}=2$. Assumed structure: square resonance hybrid. $\sigma=8$. Bond lengths $1.7 \AA \mathrm{n}_{t+b}=1 . \omega=20 \mathrm{~cm}^{-1}$.

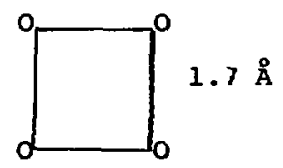

Moments of inertia:

$$
\begin{aligned}
& a=b=7.7 \times 10^{-39} \mathrm{~g} \mathrm{~cm}^{2} \\
& c=1.53 \times 10^{-38} \mathrm{~g} \mathrm{~cm}^{2} \\
& a b c=9.0 \times 10^{-115} \mathrm{~g}^{3} \mathrm{~cm}^{6}
\end{aligned}
$$

$\overline{\mathrm{H}}_{0}^{0}=-23.5 \mathrm{kcal}$ mole ${ }^{-1} \mp 0.2$ (Ref. 22)

$\bar{c}_{\mathrm{p}}^{0}(298 \mathrm{~K})=10 . \mathrm{cal} \mathrm{deg}^{-1} \mathrm{~mole}^{-1}$

$A=4.25, B=0.00125, C=D=E=0$

$\vec{s}_{\text {trans }}^{0}(298 \mathrm{~K})=39.75 \mathrm{cal} \mathrm{deg}^{-1} \mathrm{~mole}^{-1}$

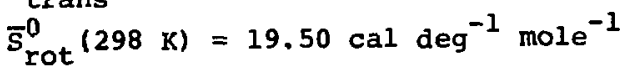

$\overline{\mathrm{s}}_{\mathrm{vib}}^{0}(298 \mathrm{k})=6.6 \mathrm{cal} \mathrm{deg}^{-1} \mathrm{~mole}^{-1}$

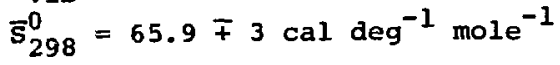

$\mathrm{J}=8.1$

$\mathrm{CO}_{3}^{-}$

$M=60 . \quad n_{\text {atoms }}=4 . \quad g_{0}=2$. Assumed structure: symmetric resonance hybrid. $\sigma=6$. All $\mathrm{C}-0$ bonds of lengths $1.18 \AA$. $n_{t+b}=1 . w=20 \mathrm{~cm}^{-1}$.

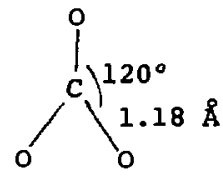

Moments of inertia:

$$
\begin{aligned}
& a=b=5.5 \times 10^{-39} \mathrm{~g} \mathrm{~cm}^{2} \\
& c=1.1 \times 10^{-38} \mathrm{~g} \mathrm{~cm}^{2} \\
& a b c=3.3 \times 10^{-115} \mathrm{~g}^{3} \mathrm{~cm}^{6} \\
& \overrightarrow{\mathrm{H}}_{0}^{0} \leq-115 \mathrm{kcal} \text { mole }{ }^{-1} \text { (Ref. } 23,24 \text { ) } \\
& \vec{C}_{p}^{0}(298 \mathrm{~K})=10 \mathrm{cal}^{\mathrm{deg}^{-1}} \mathrm{~mole}^{-1} \\
& A=4.25, B=0.00125, C=D=E=0 \\
& \bar{s}_{\text {trans }}^{0}(298 \mathrm{~K})=39.56 \mathrm{cal} \mathrm{deg}^{-1} \mathrm{~mole}^{-1} \\
& \bar{s}_{\text {rot }}^{0}(298 \mathrm{~K})=19.08 \mathrm{cal} \mathrm{deg}^{-1} \mathrm{~mole}^{-1}
\end{aligned}
$$

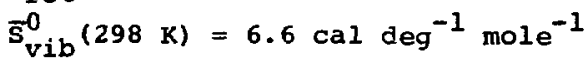

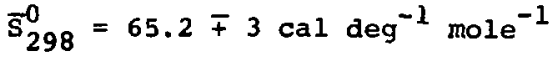

$$
\begin{aligned}
& J=7.8
\end{aligned}
$$


$\mathrm{CO}_{4}^{-}$

$\bar{M}=76 . \mathrm{n}_{\text {atoms }}=5 . \quad g_{0}=2$. Assumed structure: planar. $\sigma=2 . \mathrm{n}_{t+b}=2$. $\omega=20,20 \mathrm{~cm}^{-1}$.

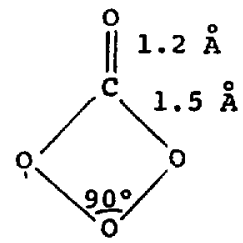

Moments of inertia:

$$
\begin{aligned}
& a=6.0 \times 10^{-39} \mathrm{~g} \mathrm{~cm}^{2} \\
& b=1.65 \times 10^{-38} \mathrm{~g} \mathrm{~cm}^{2} \\
& c=2.25 \times 10^{-38} \mathrm{~g} \mathrm{~cm}^{2} \\
& a b c=2.2 \times 10^{-114} \mathrm{~g}^{3} \mathrm{~cm}^{6}
\end{aligned}
$$

$\overline{\mathrm{H}}_{0}^{0}=-122.3 \mathrm{kcal} \mathrm{mole} \mathrm{e}^{-1} \mp 2$ (Ref. 25)

$\bar{C}_{p}^{0}(298 \mathrm{~K})=12 \mathrm{cal} \mathrm{deg}^{-1} \mathrm{~mole}^{-1}$

$A=4.95, B=0.00175, C=D=E=0$

$\overline{\mathrm{S}}_{\text {trans }}^{0}(298 \mathrm{~K})=40.27 \mathrm{cal} \mathrm{deg}^{-1} \mathrm{~mole}^{-1}$

$\overline{\mathrm{S}}_{\text {rot }}^{0}(298 \mathrm{~K})=23.15 \mathrm{cal} \mathrm{deg}^{-1} \mathrm{~mole}^{-1}$

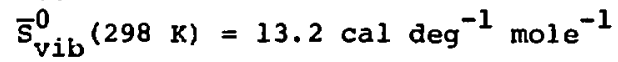

$\bar{s}_{298}^{0}=76.6 \mp 5 \mathrm{cal} \mathrm{deg}^{-1} \mathrm{~mole}^{-1}$

$\mathrm{J}=9.2$

$\frac{\mathrm{N}^{+} \cdot \mathrm{H}_{2} \mathrm{O}}{\mathrm{M}=32}$

$\mathrm{n}_{\text {atoms }}=4 . \mathrm{g}_{0}=1$. Assumed structure: planar with $2.2 \AA$ ion-dipole separation. $\sigma=2, n_{t+b}=1$. $\omega=100 \mathrm{~cm}^{-1}$.

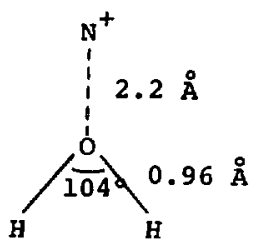

Moments of inertia:

$$
\begin{aligned}
& a=1.9 \times 10^{-40} \mathrm{~g} \mathrm{~cm}^{2} \\
& b=6.55 \times 10^{-39} \mathrm{~g} \mathrm{~cm}^{2} \\
& c=6.75 \times 10^{-39} \mathrm{~g} \mathrm{~cm}^{2} \\
& a b c=8.34 \times 10^{-117} \mathrm{~g}^{3} \mathrm{~cm}^{6}
\end{aligned}
$$

$\mathrm{N}^{+} \cdot \mathrm{H}_{2} \mathrm{O}$ (continued)

$\overrightarrow{\mathrm{H}}_{0}^{0}=+371 . \mp 5 \mathrm{kcal}$ mole $\mathrm{e}^{-1}$ (based on assumed $-18.4 \mathrm{kcal}$ heat of hydration)

$\overline{\mathrm{C}}_{\mathrm{p}}^{0}(29 \mathrm{~K} \mathrm{~K})=10 \mathrm{cal} \mathrm{deg}^{-1} \mathrm{~mole}^{-1}$

$A=4.25, B=0.00125, C=D=E=0$

$\overline{\mathrm{s}}_{\text {trans }}^{0}(298 \mathrm{~K})=36.31 \mathrm{cal} \mathrm{deg}^{-1} \mathrm{~mole}^{-1}$

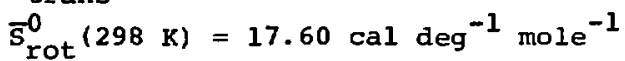

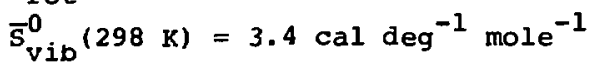

$\overline{\mathrm{s}}_{298}^{0}=57.3 \mp 4 \mathrm{cal} \mathrm{deg}^{-1} \mathrm{~mole}^{-1}$

$J=3.9$
$\frac{\mathrm{O}^{+} \cdot \mathrm{H}_{2} \mathrm{O}}{\mathrm{M}=34}, \mathrm{n}_{\text {atoms }}=4 . \quad \mathrm{g}_{0}=2 . \quad$ Assumed structure like $\mathrm{N}^{+} \cdot \mathrm{H}_{2} \mathrm{O}, \quad \sigma=2 . \mathrm{n}_{\mathrm{t}+\mathrm{b}}=1$. $\omega=100 \mathrm{~cm}^{-1}$.

Moments of inertia:

$$
\begin{aligned}
& a=1.9 \times 10^{-40} \mathrm{~g} \mathrm{~cm}^{2} \\
& b=7.33 \times 10^{-39} \mathrm{~g} \mathrm{~cm}^{2} \\
& c=7.52 \times 10^{-39} \mathrm{~g} \mathrm{~cm}^{2}
\end{aligned}
$$$$
a b c=1.04 \times 10^{-116} \mathrm{~g}^{3} \mathrm{~cm}^{6}
$$

$\bar{H}_{0}^{0}=+296$. $\mp 5 \mathrm{kcal} / \mathrm{mole}$ (based on assumed $-18.4 \mathrm{kcal}$ heat of hydration)

$\overline{\mathrm{C}}_{\mathrm{p}}^{0}(298 \mathrm{~K})=10 \mathrm{cal} \mathrm{deg}^{-1} \mathrm{~mole}^{-1}$

$\mathrm{A}=4.25, \mathrm{~B}=0.00125, \mathrm{C}=\mathrm{D}=\mathrm{E}=0$

$\bar{s}_{\text {trans }}^{0}(298 \mathrm{~K})=37.86 \mathrm{cal} \mathrm{deg}^{-1} \mathrm{~mole}^{-1}$

$\overline{\mathrm{S}}_{\text {rot }}^{0}(298 \mathrm{~K})=17.82 \mathrm{cal} \mathrm{deg}^{-1} \mathrm{~mole}^{-1}$

$\overline{\mathrm{S}}_{\text {vib }}^{0}(298 \mathrm{~K})=3.4 \mathrm{cal} \mathrm{deg}^{-1} \mathrm{~mole}^{-1}$

$\bar{s}_{298}^{0}=59.1 \mp 4 \mathrm{cal} \mathrm{deg}^{-1} \mathrm{~mole}^{-1}$ 
$\frac{\mathrm{O}^{-} \cdot \mathrm{H}_{2} \mathrm{O}}{\mathrm{N}=34}$

$n_{\text {atoms }}=4 . g_{0}=2$. Assumed structure: planar with 2.2 ion-dipole separation. $0=2 ; n_{t+b}=2$. $\omega=2 n, 100 \mathrm{~cm}^{-1}$.<smiles>O[C@H]1[CH][CH]O1</smiles>

Moments of inertia:

$a=1.9 \times 10^{-40} \mathrm{y} \mathrm{cm}^{2}$

$b=1.02 \times 10^{-38} \mathrm{~g} \mathrm{~cm}^{2}$

$c=1.04 \times 10^{-38} \mathrm{~g} \mathrm{~cm}^{2}$

$a b c-2.0 \times 10^{-116} \mathrm{~g}^{3} \mathrm{~cm}^{6}$

$\bar{H}_{0}^{0}=-50.4 \mathrm{kcal}$ mole $\mathrm{e}^{-1}$ (based on assumed -18.4 kcal heat of hydration) $\mp 3$

$\bar{C}_{p}^{0}=12$ sal $\mathrm{deg}^{-1}$ mole $e^{-1}$

$A=5.4, B=0.0010, C=D=E=0$

$\overline{\mathrm{s}}_{\text {trans }}^{0}(298 \mathrm{~K})=37.86 \mathrm{cal} \mathrm{deg}^{-1} \mathrm{~mole}^{-1}$

$\bar{s}_{\text {rot }}^{0}(298 \mathrm{~K})=18.47 \mathrm{cal} \mathrm{deg}^{-1} \mathrm{~mole} \mathrm{e}^{-1}$

$\overline{\mathrm{s}}_{\mathrm{vib}}^{0}(298 \mathrm{~K})=10 \cdot \mathrm{cal}_{\mathrm{deg}^{-1}} \mathrm{~mole}^{-1}$

$\bar{S}_{298}^{0}=66.3 \mp 6 \mathrm{cal} \mathrm{deg}^{-1} \mathrm{molle}^{-1}$

$J=2.0$

$\underline{\mathrm{OH} \cdot \mathrm{H}_{3} \mathrm{O}^{+}}$

$\vec{M}=36 . \quad n_{\text {atoms }}=6 . g_{0}=2 . \sigma=3$.

$n_{t+b}=3 . \quad \omega=50,50,500 \mathrm{~cm}^{-1}$.

$a b c=4 . \times 10^{-116} \mathrm{~g}^{3} \mathrm{~cm}^{6}$

$\bar{H}_{0}^{0}=125.3 \mathrm{kcal}$ mole $\mathrm{e}^{-1} \mp 5$ (Ref. 26)

$\bar{C}_{\mathrm{P}}^{0}=14 \mathrm{cal} \mathrm{deg}^{-1} \mathrm{~mole}^{-1}$

$A=5.65, B=0.00225, C=D=E=0$

$\overline{\mathrm{s}}_{\text {trans }}^{0}(298 \mathrm{~K})=38.03 \mathrm{cal} \mathrm{deg}^{-1} \mathrm{~mole}^{-1}$

$\bar{s}_{\text {rot }}^{0}(298 \mathrm{~K})=18.36 \mathrm{cal} \mathrm{deg}^{-1} \mathrm{~mole}^{-1}$

$\bar{s}_{v i b}^{0}(298 \mathrm{~K})=10 . \mathrm{cal} \mathrm{deg}^{-1} \mathrm{~mole}^{-1}$

$\bar{s}_{298}^{0}=66.4 \mp 10 \mathrm{cal} \mathrm{deg}^{-1} \mathrm{~mole}^{-1}$

$J=-0.2$
No dimer $\left(\mathrm{N}_{2} \mathrm{O}_{2}\right)$

$\overline{M=60 .} \mathrm{n}_{\text {atoms }}=4 . \mathrm{g}_{0}=1$. Assumed structure: planar (cis). $\sigma=2$;

$n_{t+b}=3 . \omega=20,100,1000 \mathrm{~cm}^{-1}$.

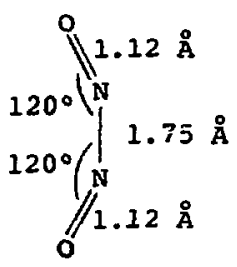

Moments of inertia:

$$
\begin{aligned}
& a=2.1 \times 10^{-39} \mathrm{~g} \mathrm{~cm}^{2} \\
& b=1.45 \times 10^{-38} \mathrm{~g} \mathrm{~cm}^{2} \\
& c=1.66 \times 10^{-38} \mathrm{~g} \mathrm{~cm}^{2}
\end{aligned}
$$$$
a b c=5.0 \times 10^{-115} \mathrm{~g}^{3} \mathrm{~cm}^{6}
$$

$\overline{\mathrm{H}}_{0}^{0}=+41.4 \mathrm{kcal}$ mole ${ }^{-1} \mp 0.2$ (Ref. 27)

$\bar{C}_{p}^{0}(298 \mathrm{~K})=14 \mathrm{cal} \mathrm{deg}^{-1} \mathrm{~mole}^{-1}$

$A=6.55, B=0.00075, C=D=E=0$

$\bar{s}_{\text {trans }}^{0}(298 \mathrm{~K})=38.19 \mathrm{cal} \mathrm{deg}^{-1} \mathrm{~mole}^{-1}$

$\bar{s}_{\text {rot }}^{0}(298 \mathrm{~K})=21.74 \mathrm{cal} \mathrm{deg}^{-1} \mathrm{~mole}^{-1}$

$\bar{s}_{\mathrm{vib}}^{0}(298 \mathrm{~K})=10 . \mathrm{cal}_{\mathrm{deg}}^{-1} \mathrm{~mole}^{-1}$

$\bar{s}_{298}^{0}=69.9 \mp 6 \mathrm{cal} \mathrm{deg}^{-1} \mathrm{~mole}^{-1}$

$\mathrm{J}=-2.6$

OONO

$M=62 . n_{\text {atoms }}=4 . g_{0}=1$. Assumed structure: planar. $\sigma=1 . n_{t+b}=3$. $\omega=20,100,1000 \mathrm{~cm}^{-1}$.

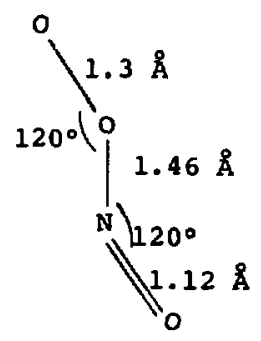

Moments of inertia:

$$
\begin{aligned}
& a=8 \times 10^{-40} \mathrm{~g} \mathrm{~cm} \\
& b=1.7 \times 10^{-38} \mathrm{~g} \mathrm{~cm}^{2} \\
& c=1.7 \times 10^{-38} \mathrm{~g} \mathrm{~cm}^{2} \\
& a b c=2.3 \times 10^{-115} \mathrm{~g}^{3} \mathrm{~cm}^{6}
\end{aligned}
$$


OONO ${ }^{-}$(continued)

$\overrightarrow{\mathrm{H}}_{0}^{0}=-50.0 \mathrm{kcal} \mathrm{mole} \mathrm{e}^{-1} \mp 8$

Estimate. $\overline{\mathrm{H}}_{0}^{0}<-46.9 \mathrm{kcal} / \mathrm{mole}$ from

Fehsenfeld et al. ${ }^{28} \overline{\mathrm{H}}_{0}^{0}>-59.2$ from DNA Handbook ${ }^{17}$ Reaction XVI-15.

$\overline{\mathrm{C}}_{\mathrm{p}}^{0}=14 \mathrm{cal} \mathrm{deg}^{-1} \mathrm{~mole}^{-1}$

$A=6.55, B=0.00075, C=D=E=0$

$\overline{\mathrm{s}}_{\text {trans }}^{0}(298 \mathrm{~K})=38.29 \mathrm{cal} \mathrm{deg}^{-1} \mathrm{~mole}^{-1}$

$\bar{s}_{\text {rot }}^{0}(298 \mathrm{~K})=22.34 \mathrm{cal} \mathrm{deg}^{-1} \mathrm{~mole}^{-1}$

$\bar{s}_{\mathrm{vib}}^{0}(298 \mathrm{~K})=10$. cal $\mathrm{deg}^{-1} \mathrm{~mole}^{-1}$

$\bar{s}_{298}^{0}=70.6 \mp 6 \mathrm{cal} \mathrm{deg}^{-1} \mathrm{~mole}^{-1}$

$\mathrm{J}=-2.2$
$\underline{\mathrm{O}_{2}^{+} \cdot \mathrm{N}_{2}}$

$M=60 . n_{\text {atoms }}=4 . g_{0}=2$. Assumed structure: planar trapezoid. $\sigma=2$. $n_{t+b}=1 . \omega=50 \mathrm{~cm}^{-1}$.

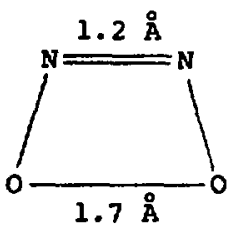

Moments of inertia:

$$
\begin{aligned}
& a=5.5 \approx 10^{-39} \mathrm{~g} \mathrm{~cm}^{2} \\
& b=1.0 \times 10^{-38} \mathrm{~g} \mathrm{~cm}^{2} \\
& \mathrm{c}=1.5 \times 10^{-38} \mathrm{~g} \mathrm{~cm}^{2} \\
& a b c=8.25 \times 10^{-115} \mathrm{~g}^{3} \mathrm{~cm}^{6} \\
& \overline{\mathrm{H}}_{0}^{0}=+272.5 \mathrm{kcal} / \mathrm{mole} \bar{\mp} 2 \text { (Ref. 22) } \\
& \overrightarrow{\mathrm{C}}_{\mathrm{p}}^{0}=10 \mathrm{cal} \mathrm{deg}^{-1} \mathrm{~mole}^{-1} \\
& A=4.25, B=0.00125, C=D=E=0 \\
& \bar{s}_{\text {trans }}^{0}(298 \mathrm{~K})=39.56 \mathrm{cal} \mathrm{deg}^{-1} \mathrm{~mole}^{-1} \\
& \vec{s}_{\text {rot }}^{0}(298 \mathrm{~K})=22.17 \mathrm{cal} \mathrm{deg}^{-1} \mathrm{~mole}^{-1} \\
& \vec{s}_{\mathrm{vib}}^{0}(298 \mathrm{~K})=4.8 \mathrm{cal} \mathrm{deg}^{-1} \mathrm{~mole}^{-1} \\
& \bar{s}_{298}^{0}=66.5 \mp 3 \mathrm{cal} \mathrm{deg}^{-1} \mathrm{~mole}^{-1}
\end{aligned}
$$$$
\mathrm{J}=8.5
$$

$\underline{\mathrm{O}_{2}^{-} \cdot \mathrm{N}_{2}}$

Dissociation energy $\mathrm{D}\left(\mathrm{O}_{2}^{-} \cdot \mathrm{O}_{2}\right)=13.6 \mathrm{kcal} /$ mole. ${ }^{30}$ We assume $\mathrm{D}\left(\mathrm{O}_{2}^{-} \cdot \mathrm{N}_{2}\right)=5 \mathrm{kcal} / \mathrm{mole}$, and assume same $\overrightarrow{\mathrm{C}}_{\mathrm{p}}^{0}$ and $\overrightarrow{\mathrm{s}}^{-}$as for $\mathrm{O}_{2}^{+} \cdot \mathrm{N}_{2}$.

Therefore

$\overline{\mathrm{H}}_{0}^{0} \approx-14.9 \mp 5 \mathrm{kcal} \mathrm{mole}^{-1}$

$\bar{C}_{\mathrm{p}}^{0}(298 \mathrm{~K})=10 . \mathrm{cal}_{\mathrm{deg}}^{-1} \mathrm{~mole}^{-1}$

$A=4.25, B=0.00125, C=D=E=0$

$\vec{s}_{298}^{0}=66.5 \mp 3 \mathrm{cal} \mathrm{deg}^{-1} \mathrm{~mole}^{-1}$

$\mathrm{J}=8.5$

$\mathrm{CO}_{3}$

Moments of inertia, $\overline{\mathrm{C}}_{-}^{0}, A$, and $B$ same as those assumed for $\mathrm{CO}_{3}^{-} \cdot \mathrm{g}=1$.

$\overline{\mathrm{H}}_{0}^{0}=-43 \mp 5 \mathrm{kcal} / \mathrm{mole} \mathrm{e}^{24,31}$

$\bar{s}_{298}^{0}=63.8 \mp 3 \mathrm{cal} \mathrm{deg}^{-1} \mathrm{~mole}^{-1}$

$\mathrm{J}=7.1$
The remainder of the species in this list, all hydrated diatomic and polyatomic ions, are assumed to have no symmetry (i.e. $\sigma=1$ ), and their moment of inertia products are assumed to be given by the approximation abc $=7.4 \times 10^{-122} \mathrm{M}^{3} \mathrm{n}_{\text {atoms }}^{2}\left(\mathrm{~g}^{3} \mathrm{~cm}^{6}\right)$. This is equivalent to assuming that the molecule behaves as a uniform sphere of mass $1.66 \times 10^{-24} \mathrm{M}(\mathrm{g})$ and volume $2 \times 10^{-24} \mathrm{n}_{\text {atoms }}\left(\mathrm{cm}^{3}\right)$. Furthermore, we assume that $n_{t+b}$ is equal to the number of atoms minus twice the number of attached water molecules, and each of the $n_{t+b}$ modes has the same fundamental frequency $100 \mathrm{~cm}^{-1}$. The multiplicity $g_{0}$ is assumed to be 1 if the total number of electrons is even, and 2 if the number is odd. With these assumptions the $298 \mathrm{~K}$ entropy is given by 


$$
\begin{aligned}
\bar{s}_{298}^{0}= & R\left[16.8+3 \ln M+\ln \left(n_{\text {atoms }}\right)\right. \\
& \left.+\ln g_{0}+1.7\left(1+n_{\text {atoms }}-2 n_{w}\right)\right] .
\end{aligned}
$$

The $298 \mathrm{~K}$ specific heat is

$$
C_{p}^{0}(298 K)=R\left(4+n_{\text {atoms }}-2 n_{\text {water }}\right) \text {. }
$$

with a probable inaccuracy of about $\mp 5 \mathrm{cal} \mathrm{deg}^{-1}$ mole $\mathrm{d}^{-1}$. Heats of formation are derived from those of the parent ions and the assumed heats of hydration specified in Section III. The results are listed in Table AI.

\begin{tabular}{|c|c|c|c|c|c|c|c|c|c|c|}
\hline Ion & $M$ & natoms & $\begin{array}{l}1+n_{\text {atoms }} \\
-2 n_{W} \\
\end{array}$ & $\underline{g_{0}}$ & A & B & $\bar{s}_{298}^{0}$ & $J$ & $\bar{H}_{0}^{0}$ & Ref \\
\hline $\mathrm{wH}_{3} \mathrm{o}^{+}$ & 37 & 7 & 6 & 1 & 7.5 & 0.0025 & 79. & -4.5 & +49.9 & 14 \\
\hline mino ${ }^{+}$ & 48 & 5 & 4 & 1 & 6.1 & 0.0015 & 73. & 1.1 & +158 & \\
\hline $\mathrm{NNO}_{2}^{+}$ & 64 & 6 & 5 & 1 & 6.8 & 0.0020 & 79. & -0.4 & +157 & \\
\hline $\mathrm{WN}_{2}^{+}$ & 46 & 5 & 4 & 2 & 6.1 & 0.0015 & 74. & 1.7 & +282 & \\
\hline $\mathrm{Ho}_{2}^{+}$ & 50 & 5 & 4 & 2 & 6.1 & 0.0015 & 75. & 2.0 & +201 & \\
\hline $\mathrm{WCO}_{3}^{-}$ & 78 & 7 & 6 & 2 & 7.5 & 0.0025 & 85. & -1.3 & -181.6 & 24 \\
\hline $\mathrm{wCO}_{4}^{-}$ & 94 & 8 & 7 & 2 & 8.2 & 0.0030 & 90. & -3.4 & -193.7 & 29 \\
\hline $\mathrm{WOH}^{-}$ & 35 & 5 & 4 & 1 & 6.1 & 0.0015 & 71. & 0.2 & -112.4 & 13 \\
\hline WNO ${ }^{-}$ & 48 & 5 & 4 & 1 & 6.1 & 0.0015 & 73. & 1.1 & -55 & \\
\hline $\mathrm{WNO}_{2}^{-}$ & 64 & 6 & 5 & 1 & 6.8 & 0.0020 & 79. & -0.4 & -117.7 & 29 \\
\hline $\mathrm{WNO}_{3}^{-}$ & 80 & 7 & 6 & 1 & 7.5 & 0.0025 & 84. & -2.1 & -136.3 & 29 \\
\hline $\mathrm{wo}_{2}^{-}$ & 50 & 5 & 4 & 2 & 6.1 & 0.0015 & 75. & 2.0 & -85.4 & 13 \\
\hline $\mathrm{WO}_{3}^{-}$ & 66 & 6 & 5 & 2 & 6.8 & 0.0020 & 80 . & 0.4 & -85 & \\
\hline $\mathrm{wo}_{4}^{-}$ & 82 & 7 & 6 & 2 & 7.5 & 0.0025 & 85. & -1.4 & -99. & \\
\hline $\mathrm{w}_{2} \mathrm{H}_{3} \mathrm{O}^{+}$ & 55 & 10 & 7 & 1 & 7.3 & 0.0045 & 86. & -1.3 & -29.5 & \\
\hline $\mathrm{w}_{2} \mathrm{NO}^{+}$ & 66 & 8 & 5 & 1 & 5.9 & 0.0035 & 79. & 4.2 & +78.6 & \\
\hline $\mathrm{w}_{2} \mathrm{O}_{2}^{+}$ & 68 & 8 & 5 & 2 & 5.9 & 0.0035 & 81 . & 5.0 & +122 & \\
\hline $\mathrm{w}_{2} \mathrm{CO}_{3}^{-}$ & 96 & 10 & 7 & 2 & 7.3 & 0.0045 & 90. & 1.1 & -258 & \\
\hline $\mathrm{w}_{2} \mathrm{CO}_{4}^{-}$ & 112 & 11 & 8 & 2 & 8.0 & 0.0050 & 95. & -0.9 & -265 & \\
\hline $\mathrm{w}_{2} \mathrm{NO}_{3}^{-}$ & 98 & 10 & 7 & 1 & 7.3 & 0.0045 & 89. & 0.4 & -210 & \\
\hline $\mathrm{w}_{2} \mathrm{O}_{2}^{-}$ & 68 & 8 & 5 & 2 & 5.9 & 0.0035 & 81. & 5.0 & -159.7 & 13 \\
\hline $\mathrm{w}_{2} \mathrm{O}_{4}^{-}$ & 100 & 10 & 7 & 2 & 7.3 & 0.0045 & 90. & 1.1 & -167 & \\
\hline $\mathrm{w}_{2} \mathrm{OH}^{-}$ & 53 & 8 & 5 & 1 & 5.9 & 0.0035 & 78. & 3.6 & -185.9 & 13 \\
\hline $\mathrm{w}_{3} \mathrm{H}_{3} \mathrm{O}^{+}$ & 73 & 13 & B & 1 & 7.1 & 0.0065 & 91. & 1.4 & -104 & \\
\hline $\mathrm{w}_{3} \mathrm{No}^{+}$ & 84 & 11 & 6 & 1 & 5.7 & 0.0055 & 85. & 6.9 & +4.5 & \\
\hline$w_{3} O_{2}^{-}$ & 86 & 11 & 6 & 2 & 5.7 & 0.0055 & 86. & 7.6 & -232.2 & 13 \\
\hline
\end{tabular}

TABLE AI

CALCULATED THERMODYNAMIC PARAMETERS FOR THE MORE COMPLEX IONS 


\section{REFERENCES}

1. F. R. Gilmore, "Equilibrium Composition and Thermodynamic Properties of Air to $24000^{\circ} \mathrm{K}, "$ Rand Corp. report RM-1543 (August 1955).

2. F. R. Gilmore, R\&D Associates, Santa Monica, CA, private communication, March 1974 .

3. J. Hilsenrath and M. Klein, "Tables of Thermodynamic Properties of Air in Chemical Equilibrium Including second Virial corrections from $1500^{\circ} \mathrm{K}$ to $15,000^{\circ} \mathrm{K}, "$ Arnold Engineering Development Center, Air Force Systems Command report AEDC-TDR-63-161 (August 1963).

4. J. Hilsenrath, M. C. Green and C. W. Beckett, "Thermodynamic Properties of Highly Ionized Air," Air Force Special Weapons Center report AFSWC-TR-65-35 (April 1957).

5. C. D. Sutherland and J. Zinn, "Chemistry Computations in Irradiated Hot Air," Los Alamos Scientific Laboratory report in preparation.

6. D. R. Stull, JANAF Thermochemical Tables (Dept. of Commerce, National Bureau of Standards, Washington, DC, 1970).

7. F. Van Zeggeren and S. H. Storey, The Computation of Chemical Equilibria (Cambriage University press, 1970).

8. F. R. Gilmore, "Thermal Radiation Phenomena," Vol. I, Lockheed Missiles and Space Co. report IMSC-3-27-67-1 (DASA-1917-1) (May 1967).

9. J. Hilsenrath, C. G. Messina, and W. H. Evans, "Tables of Ideal Gas Thermodynamic Functions for 73 Atoms and Their First and Second Ions to $10,000^{\circ} \mathrm{K}, "$ National Bureau of Standards, Washington, DC, Air Force Weapons Laboratory report AFWL TDR-64-44 (August 1964).

10. L. V. Gurvich, Thermodynamic Properties for the Chemical Species of the Hydrogen-Air system (Publishing House of the Academy of Sciences of the USSR, Moscow, 1962).

11. David G. Clifton, "Approximate Thermodynamic Functions for the $\mathrm{NO}^{-}(\mathrm{g})$, $\mathrm{OH}^{-}(\mathrm{g})$, $\mathrm{OH}^{+}(\mathrm{g})$ Ions," General Motors Defense Research Laboratories report TRGG-01C (April 1966).

12. P. G. Bird, R. E. Duff, and G. L. Schott, "HUG, a Fortran-FAP code for Computing Normal shock and Detonation Wave Parameters in Gases," Los Alamos Scientific Laboratory report IA-2980 (February 1964).
13. M. Arshadi and P. Kebarle, "Hydration of $\mathrm{OH}^{-}$and $\mathrm{O}_{2}^{-}$in the Gas Phase," J. Phys. Chem. 74, 1483 (1970).

14. P. Kebarle, S. K. Searles, A. Zolla, $\mathrm{J}$. Scarborough, and M. Arshadi, "The Solvation of the Hydrogen Ion by Water Molecules in the Gas Phase. Heats and Entropies of Solvation of Individual Reactions: $\mathrm{H}^{+}\left(\mathrm{H}_{2} \mathrm{O}\right)_{\mathrm{n}-1}+\mathrm{H}_{2} \mathrm{O}-\mathrm{H}^{+}\left(\mathrm{H}_{2} \mathrm{O}\right)_{n}{ }^{\prime \prime}$ J. Am. Chem. Soc. 89, 6393 (1967).

15. S. Glasstone, Thermodynamics for Chemists (D. Van Nostrand Co., New York, NY, 1947).

16. R. M. Moyerman and K. E. Shuler, "The Concentration of Contaminant Alkali Salts in Ground Level Air," Science 118,612 (1953).

17. Defense Nuclear Agency Reaction Rate Handbook, Second Edition, DNA 1948H, General Electric TEMPO (November 1972).

18. C. W. Allen, Astrophysical Quantities (University of London, The Athione Press, 1963).

19. D. A. Parkes and T. M. Sugden, "Electron Attachment and Detachment in Nitric oxide," Chemical Society of Iondon, Faraday Transactions 2,600 (1972).

20. A. Good, D. A. Durden, P. Kebarle, "Ion-Molecule Reactions in Pure Nitrogen and Nitrogen Containing Traces of Water, etc.," J. Chem. Phys. 52, 212 (1970).

21. D. A. Durden, P. Kebarle, A. Good, "Thermal Ion-Molecule Reaction Rate Constants, Reactions in Methane, Krypton, and oxygen," J. Chem. Phys. 50, 805 (1969).

22. D. C. Conway and I. E. Nesbitt, "Stability of $\mathrm{O}_{4}^{-}, " \mathrm{~J}$. Chem. Phys. 48,509 (1968).

23. J. T. Moseley, R. A. Bennett and J, R. Peterson, "Photodissociation of $\mathrm{CO}_{\overline{3}}, "$ USA Ballistic Research Laboratories report BRL CR 144 (March 1974).

24. E. E. Ferguson, F. C. Fehsenfeld and A. V. Phelps, "Comment on Photodetachment Cross sections for $\mathrm{CO}_{3}$ and Its First Hydrate," J. Chem. Phys. 59, 1565 (1973).

25. J. L. Pack and A. V. Phelps, "Electron Attachment and Detachment II. Mixtures of $\mathrm{O}_{2}$ and $\mathrm{CO}_{2}$ and of $\mathrm{O}_{2}$ and $\mathrm{H}_{2} \mathrm{O}$," J. Chem. Phys. 45, 4316 (1966).

26. A. Good, D. A. Durden and P. Kebarle, "Mechanism and Rate Constants of IonMolecule Reactions Leading to Formation of $\mathrm{H}^{+} \cdot\left(\mathrm{H}_{2} \mathrm{O}\right)$ in Moist oxygen and Air," J. Chem. Phys. 52, 222 (1970). 
27. J. 81111ngsley and A. B. Callear, "xavestigation of the 2050 A syaten of the Nitrie oxide Diwor," Trins. Par. Soc. 67. 589 (197).

28. F. C. Fehsenfeld, A. t. Setmeleckopk. H. I. Schtff and E. E. Parquson. Notetive Ion Resctions of Atmospheric Interest." Planet. Space Sel. 25. 37J (1967).

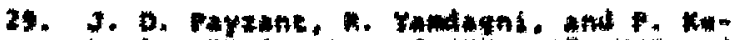

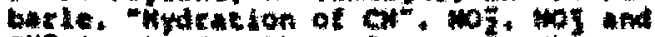

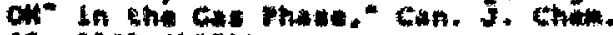
49. $310 \%$ (17)11.

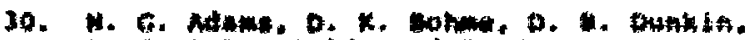

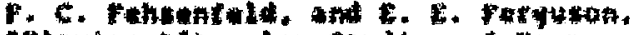

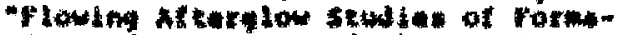

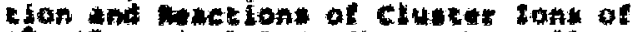

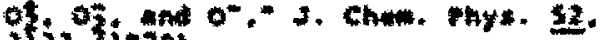
11) tipos.

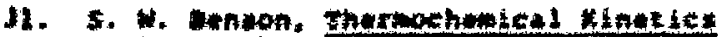

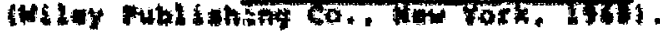

